حضارة الهضبة الايرانية من الالف الخامس قبل الميلاد حتى نهاية العهد الميدي • هـق.م.

أ.م.د.ميثم عبد الكاظم جواد النوري

جامعة بغداد - كلية الاداب
أ.م.د. مهدية فيصل صالح الموسوي

جامعة بذاد كلية التربية بن رشد

\title{
ملغص بحث
}

ان العوامل المؤثرة في خلق كل حضارة تتبع من الواقع المادي والفكري اي من فكر المجتمع ودينه وعاداته ، فتقافة الانسان الاولى ما هي الا وليدة ناثره بالبيئة التي حوله ، والهضبة الايرانية واحدة من بلدان العالم القديم التي امتازت ارضها بالتتوع والتباين الجغرافي على امتداد مسحتها الجغرافية ، فكان لذللك التباين

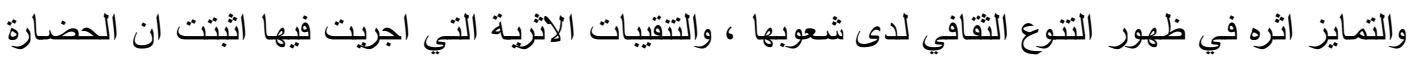

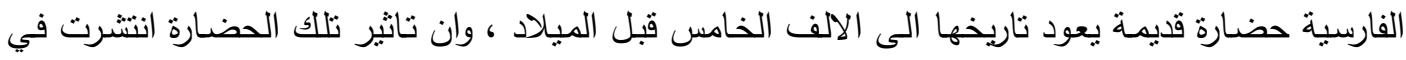

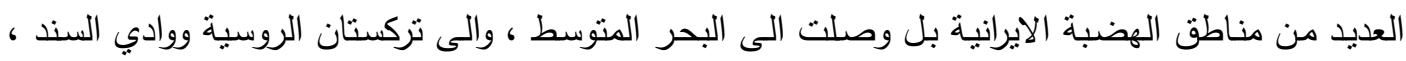

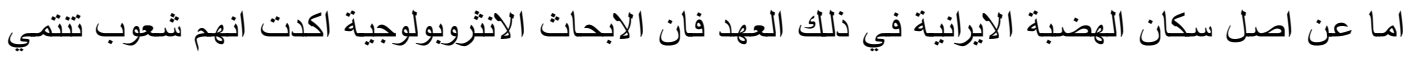

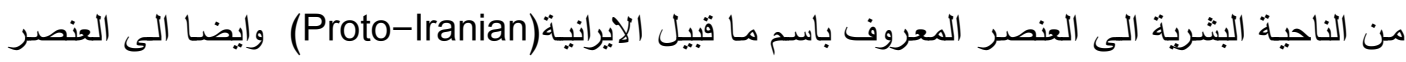
المعروف باسم ما قبيل البحر المتوسط (Proto-Aediterenean) ، ولم يدخل من مناطق الهضبة الهبة الايرانية في العصور التاريخية في الالف الثالث قبل الميلاد سوء الجزء الجنوبي الغربي منها اذ تمكن العيلاميون وهم جنس من اصل اسياني او قوقازي - من اقامسة مركزا حضاريا لهم في سوسة ، ومع ان حضارتهم وثيقة

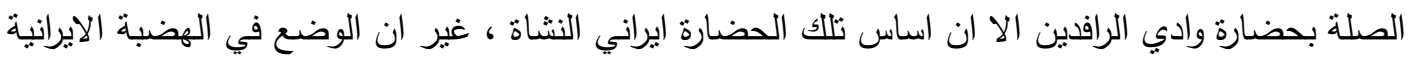
تغير في الالف الثاني قبل الميلاد اذ شهـ ذلك العهد ظهور شعوب عدة في غرب اسيا بعد ان هجرت

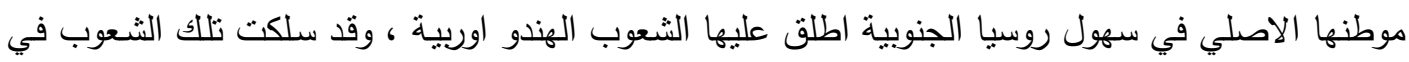
هجرتها طريقين رئيسيين قسم اتجه الى الغرب ، والقسم الثاني اتجه الى الثرق وعرف باسم الثعوب الهندو -

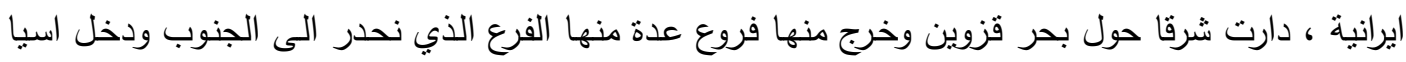
الوسطى وهولاء هم الاريون الذين سكنوا مناطق جنوب بحر ارال ، وبحدود سنة . .11 قبل الميلاد تفرق الئه

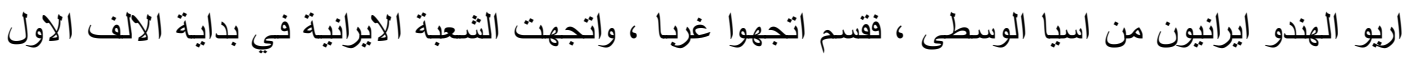

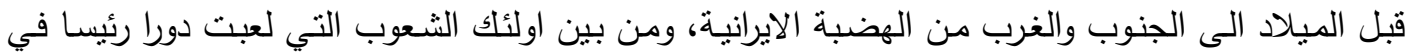




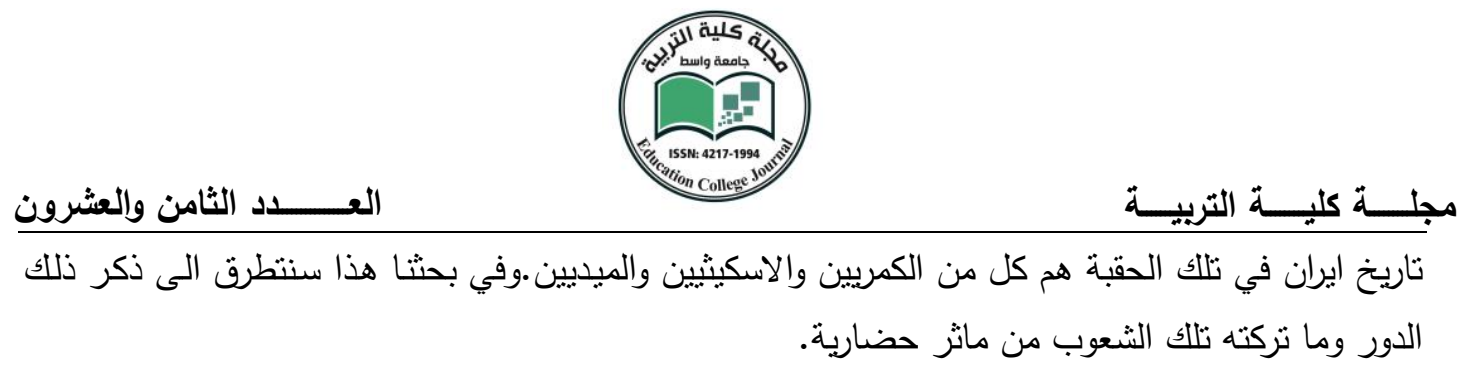

\title{
The Civilization of the Iranian Plateau from the Fifth Millennium BC to the End of the Reign of Medias $550 \mathrm{BC}$
}

\author{
Assist. Prof.Dr. Mahdiyah F. Saleh Al-Musawi \\ College of Education Ibn Rushd \\ Baghdad University
}

Assist. Prof.Dr. Maytham A. Jawad Al-Noori
College of Literature
Baghdad University

ABSTARCT

The effected factors on the creation of each civilization is stem from the physical and intellectual reality of the society's and its religion and culture, so, the first human culture is just a result of its influence on the environment around it, therefore, he Iranian plateau is one of the countries of the ancient world that its land have the difference and differentiation in its impact on the emergence of cultural diversity among its peoples, and the archaeological excavations is proved that the Persian civilization is an ancient civilization and dating back to the Fifth Millennium BC, and that the impact of this civilization spread in many areas of the Iranian plateau, and it reached to the Mediterranean Sea, Russian, Turkestan, and the Sindh Valley, besides, the origin of the Iranian plateau population, the research on anthropological is confirmed that they are belong to the human side to the element that known as (Proto-Iranian) and also to the element that known as (Proto-Mediterenean), and they did not enter the areas of ranian plateau before the Third Millennium BC (only the south-western part), and the Elamites they race out of Asian or Caucasian - is established their cultural center in Sousse, and in spite of their civilization closely related to the civilization of Mesopotamia, but the basis of that upbringing of it is an Iranian in creation, and the situation in this plateau is changed in the Second Millennium BC, because it suffers from appearnce of other pepeles came from West Asia after being abandoned from its native region in steppes of southern Russia, called the Indo-European peoples, where these peoples are headed two main ways to the west, while the others are headed to the east and was known as the Indo-Iranian peoples, and then went to eastward around the Caspian Sea and then a several branches came out of it, including the branch that descends to the south and entered Central Asia and one of 
them are the Arians who inhabited the south Aral Sea, and up to the year $1800 \mathrm{BC}$ dispersed the Arian-Indo-Iranian from Central Asia, that why some divided and turned to west, while others are headed to the south and west of the Iranian plateau at the beginning of the First Millennium BC, and among the peoples of those who played a key role in Iran's history in that era they are Al Cimmeriens, Al Scythians, and Medias. In this research we will discuss and deals with the role and the impact of those peoples of the cultural exploits in civilaization. 


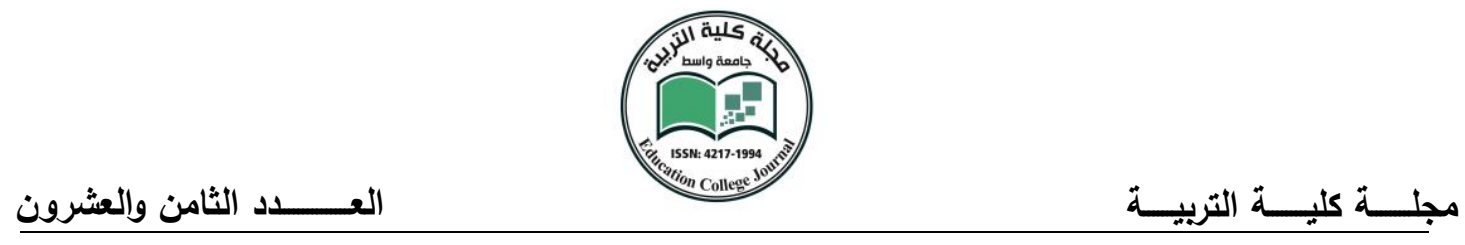

حضارة الهضبة الايرانية من الالف الخامس قبل الميلاد حتى نهاية العهد الميدي •همق.م .

ان العوامل المؤثرة في خلق كل حضارة تتبع من الواقع المادي والفكري اي من فكر المجتمع ودينه وعاداته ، فتقافة الانسان الاولى ما هي الا وليدة تاثره بالبيئة التي حوله ، والهضبة الايرانية واحدة من بلدان العالم القديم التي امتازت ارضها بالتتوع والتباين الجغرافي على امتداد مسحتها الجغرافية ، فكان لذلك التباين والتمايز اثره في ظهور التتوع الثقافي لدى شعوبها ، والتتقيبات الاثرية(1) التي اجربت في الهضبة الايرانية اثتبت ان الحضارة الفارسية حضارة قديمة يعود تاريخها الى الالف الخامس قبل الميلاد واهم مراكزها قرية سياللك(Sialk) الواقعة شمال غرب ايران على مقربة من مدينة كاشان في الجنوب الثرقي من طهران(r) ،فما خلفه سكان تلك القربة يدل على انهم كانوا ذو حضارة ،عاشوا في مجتمعات زراعية مستقرة ، وعرفوا بناء المنازل التي كانت في اول امرها عبارة عن اكواخ بسيطة شيدت من اغصان الاشجار كسيت بالكتل الطينية لتساعد على تماسكها ، وفي مرحلة لاحقة استعملوا الطين لبناء جدران منازلهم التي اتخذت شكل مستطيل في تخطيطه ، ومن خلال الملاحظة والتجربة ومحاولة تسخير امكانات البيئة المحيطة بهم مع ما يتفق ومنطلبات الحياة عرفوا طلاء جدران منازلهم باللون الاحمر المستخرج من اوكسيد الحديد الموجود بكثرة في

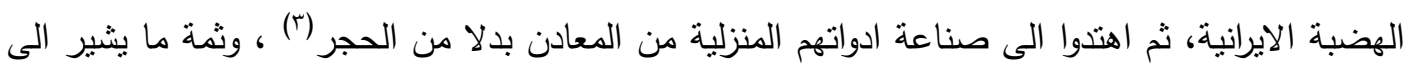
انهم كانوا ذو ميول فنية اشبعوها بنحتهم على العظام ، كما عبروا عنها بصنع الاواني الفخارية بايديهم فبل معرفتهم بدولاب الفخار، وتفنتوا في صنعها فكانوا يشكلون ايدي تلك الاواني على هيئة قرون الغزلان او

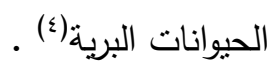

ومن المظاهر الحضارية لتلك المرحلة ايضاً، اهتمام انسان الهضبة الايرانية بمصيره بعد الموت ، فدفنهم للموتى كان ينم بطريقة تدل على الاعثقاد بالحياة في العالم الاخر ، اذا كان دفن يتم في اول الامر اسفل ارضية المنازل في وضع مقرفص ، وينثز فوق جثة المتوفي قبل دفنه التراب الاحمر (ن)ويرى الباحثون ان الغاية من ذلك اعطاء الحياة لصاحب الجثة ، على اعتبار ان اللون الاحمر يرمز الى الدم الذي يعبر جريانه في جسد الانسان على تمتعه بالحياة وفي ذلك دلالة على ايمان اصحاب نلك الحضارة بالحياة الاخرى(؟) ، وفي الحقبة القربية من العصر التاريخي حدث تغبير في طريقة دفن الموتى اذ اتجه سكان الهضبة الايرانية الى فصل المقابر عن المدن ، فكانوا يقيمونها الى الغرب من مدنهم ، وكانوا يختارون لمقابرهم الارضي السهلية في حين ان منازلهم كانوا يشيدونها على ربوات مرتفعة ، فكانت المقابر عبارة عن كنه كله 
حفر تحفر في الارض وبعد ان يقبر الموتى يوضع معهم الاثاث الجنائزي الخاص به ، ثم تغطى الحفرة بكتل

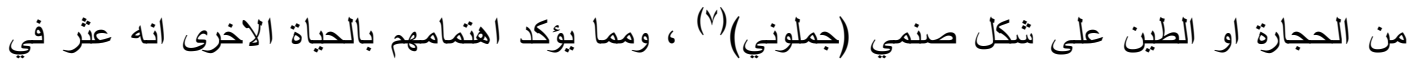
مقبرة في التل الثمالي من تبة سياللك على فاس وضعت في متتاول يد المتوفي،وعلى تجهيزات جنائزية

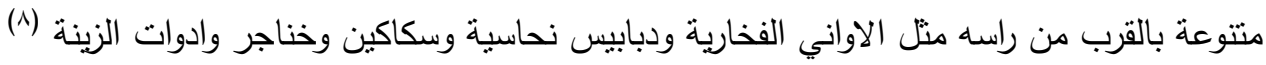

ومما ينبغي الاشارة اليه ان سكان منطقة سيالك ومناطق حضارية اخرى(9) في الهضبة الايرانية

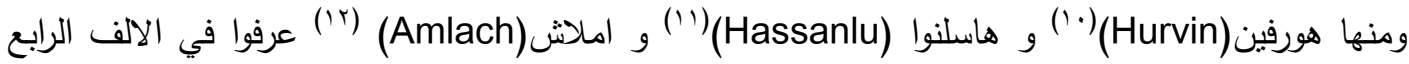
قبل الميلاد دولاب الفذار وهذا يعني ان المرحلة الاولى لفن الهضبة الايرانية المحلي ترجع الى الالف الرابع

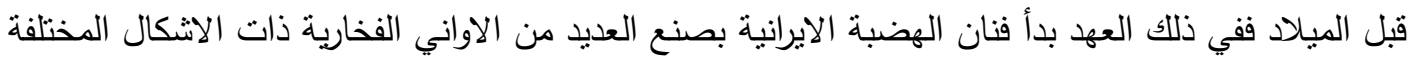
متل الكؤوس والاقداح وغيرهما من ادوات الحياة العملية اليومية مزينة برسوم الحيوانات الموجودة في بيئته الائه

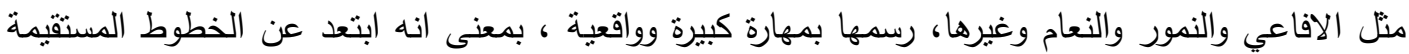

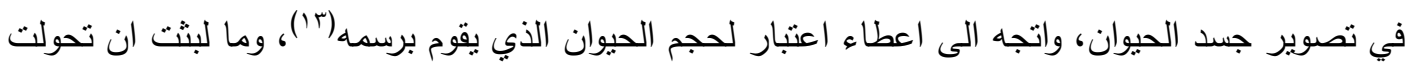

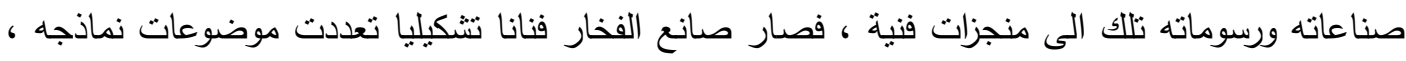
فمنها مناظر الصيد التي تمنلىء بمناظر الصراع مع الحيوانات ، ومنها قرابين نذرية للالهة المسؤولة عن

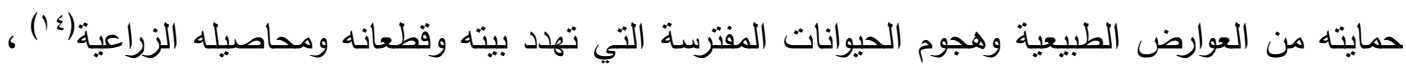

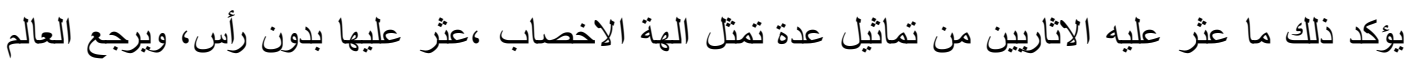

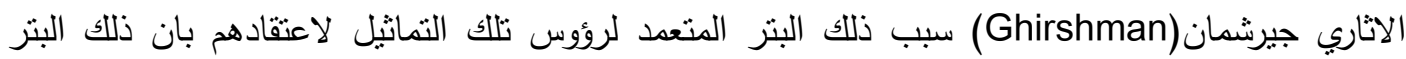

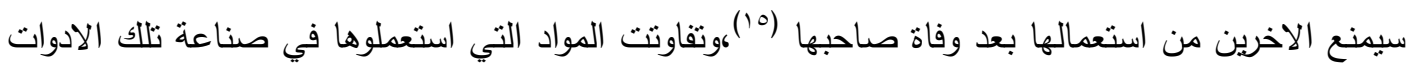

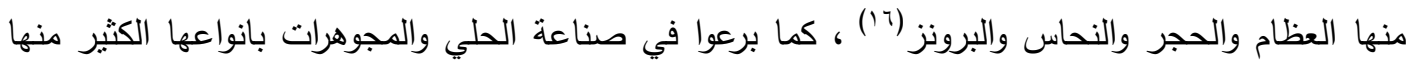

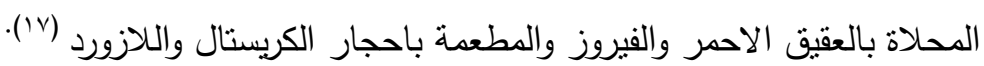

ومن الادلة الاثرية التي تثبت نطور صناعة انسان ذلك العهد واتساع نشاطه التجارية هي الاختام

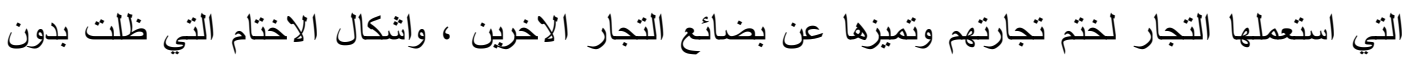
تغيير لفترة طويلة كانت عبارة عن قطعة حجرية ذات شكل كمثري مزودة بحبل منقوش عليها اثنكال ورموز

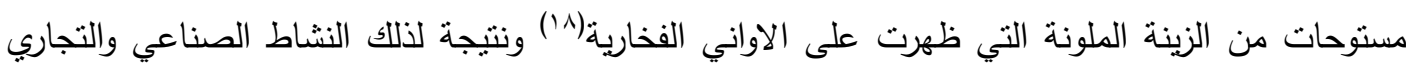




\section{العــــــد الثامن وإلعشرون}

مجلــــة كليــــة التربيـــة

انتشرت حضارة سيالك في العديد من مناطق الهضبة الايرانية بل وصلت الى البحر المنوسط ، والى لى لئل

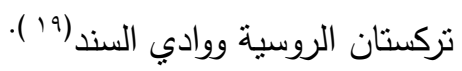

اما عن اصل سكان الهضبة الايرانية في ذلك العهد فان الابحاث الاتثروبولوجية اكدت انهم شعوب

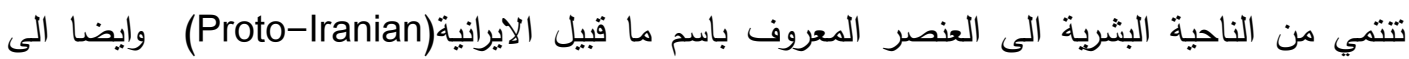
العنصر المعروف باسم ما قبيل البحر المتوسط (Proto-Aediterenean)(r.).

لم يدخل من مناطق الهضبة الايرانية في العصور التاريخية في الالف الثالث قبل الميلاد سوى

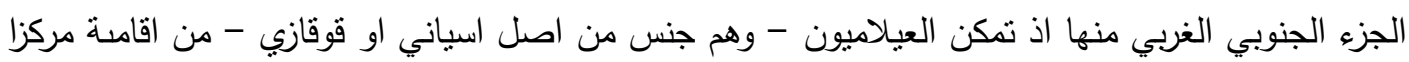

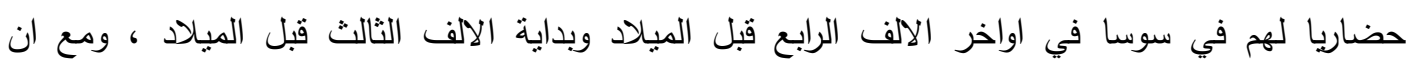
حضارتهم وثيقة الصلة بحضارة وادي الرافدين الا ان الذي يجب تاكيده ان اساس تلك الحضارة ايراني النشاة،

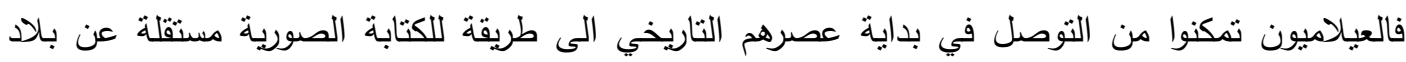

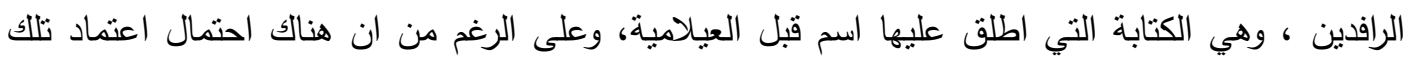

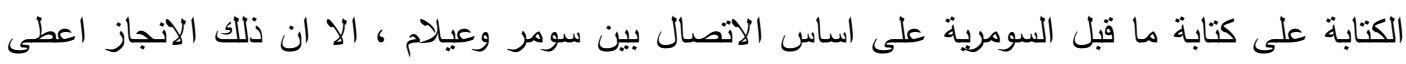

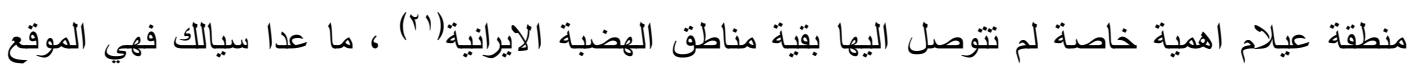

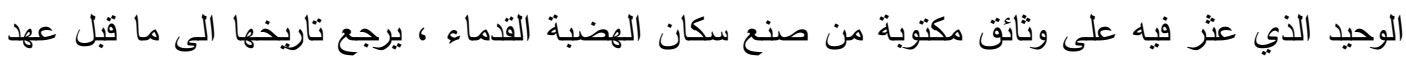

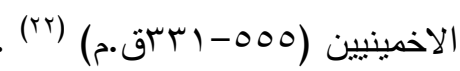

والراجح ان الصعوبات الطبيعية التي اتصفت بها الهضبة الايرانيبة كان لها الاثر المهم في تضييق نطاق الاتصال بين المجتمعات المنتشرة في شمال وجنوب وغرب وجنوب وشرق ووسط لائل (ايران)

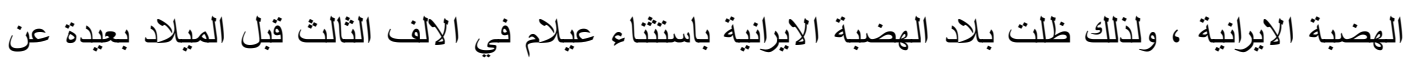

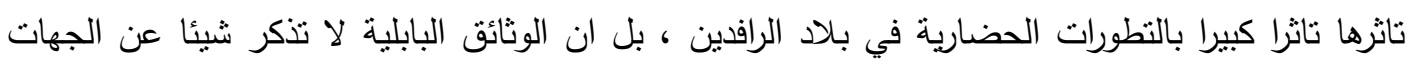

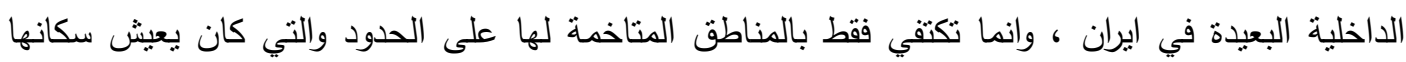

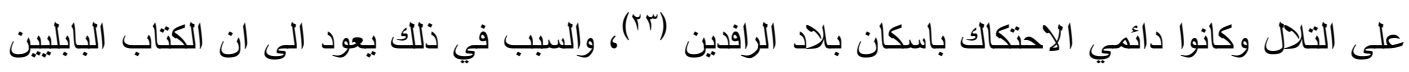

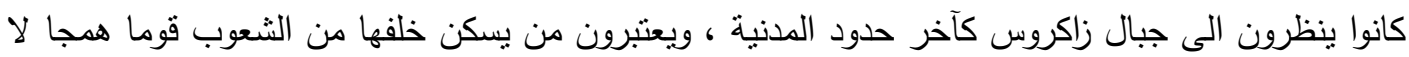

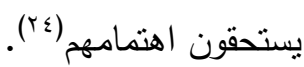


اما سكان التلال فيقصد بهم الاقوام التي سكنت المناطق جبال زاكروس ذات الاصل الاسياني او

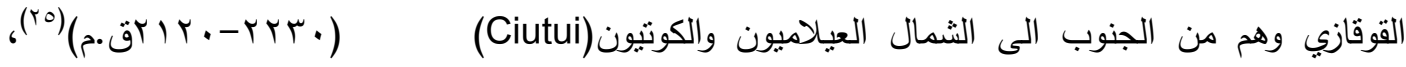

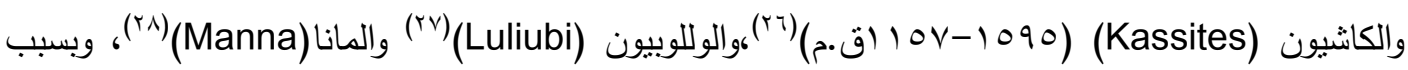
سيطرتهم على الجبال المتحكمة في الطريق المؤدي الى غرب ايران فقد تحكموا بحركة القوافل التجارية

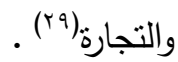

ولم يكن لهؤلاء في الالف الثالث او الالف الثاني قبل الميلاد وحدة قوية ، بل ظلت قبائل متفرقة

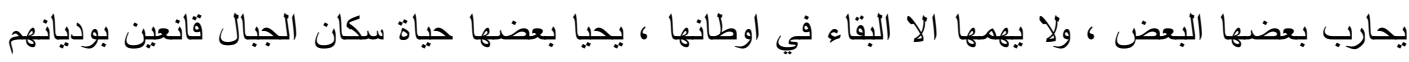
الخصبة القليلة ومعتدين على مراعيهر وعلى ما يجنونه من التجارة(·r).

غير ان الوضـع في الهضبة الايرانية تغير في الالف الثاني قبل الميلاد اذ شهـ ذلك العهد ظهور

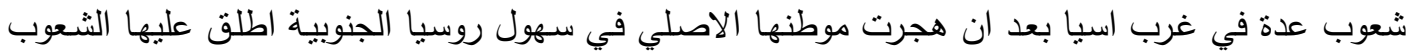

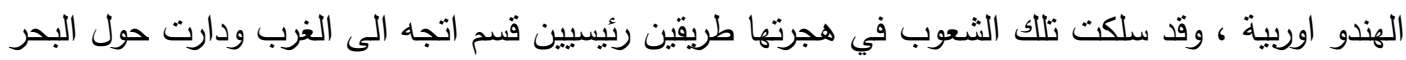

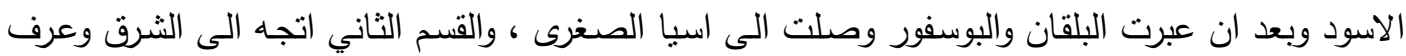

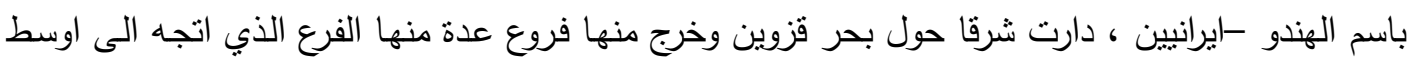

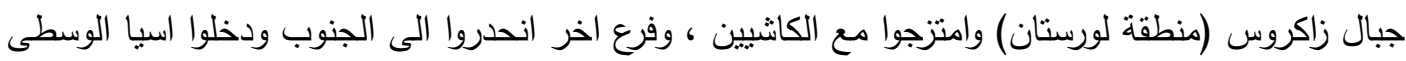

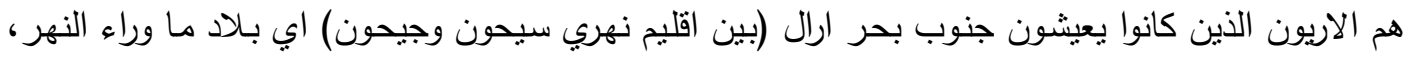

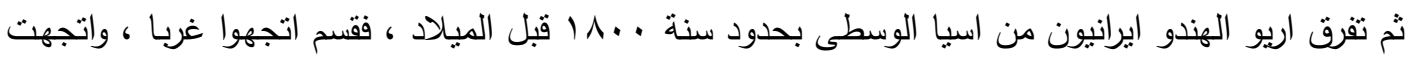

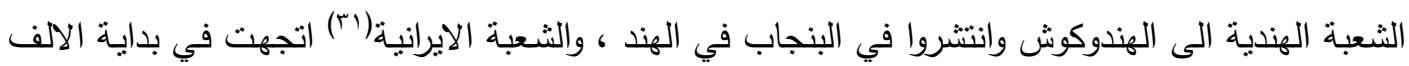

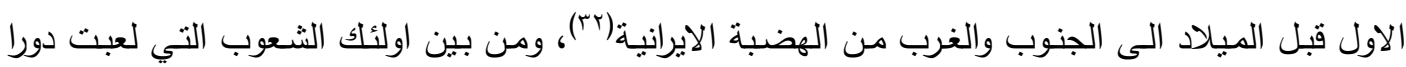
رئيسا في تاريخ ايران في تلك الحقبة هم كل من الكمريين والاسكيثيين والميديين.

\section{1 الكيمريين (Cimmeriens)}

لم تدخل القبائل الهندو ايرانية الارية الهضبة الايرانية دفعة واحدة ، ولم بسلكوا طريقا

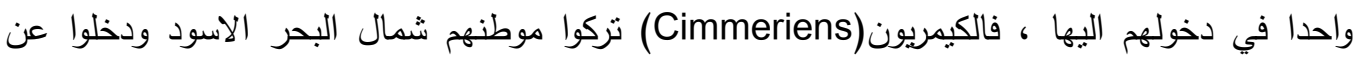
طريق القوقاز في القرن الثامن قبل الميلاد الى الهضبة الايرانية ، واول الدول التي اصطدموا بها بها وازحوها 


\section{العـــــــد الثامن والعشرون}

\section{مجلــــة كليــــة التربيــــة}

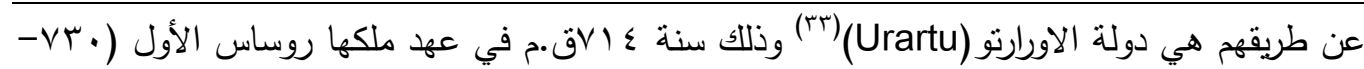

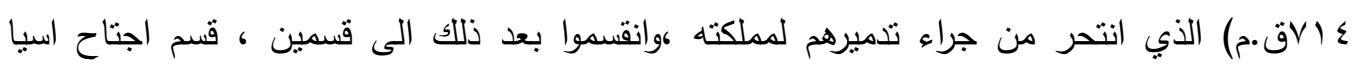

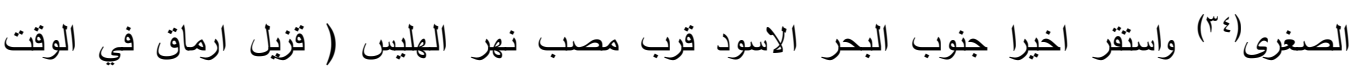

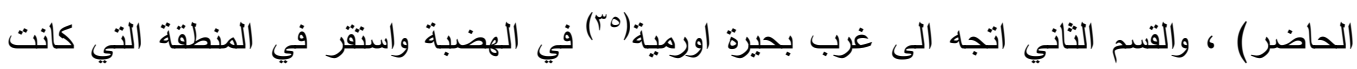
تحمل اسم الكاشيين الذين تسموا بعد ذلك باللوريستانيين( آحان.

لم تذكر لنا المصادر المتوفرة بين ايدينا شيء عن ثقافتهم وعقائدهم الدينية في المنطقة القوقازية التي

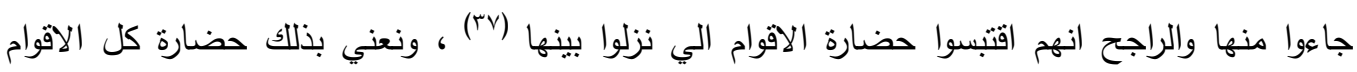

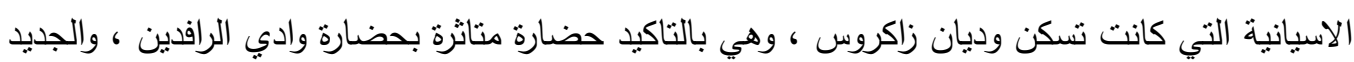

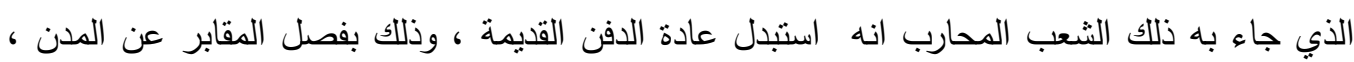

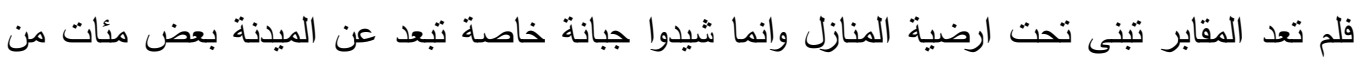

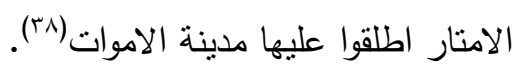

يظهر من مخلفاتها انهم اناس اقوياء وفرسان مهرة ، اذ كانوا يدفنون مع موتاهم جيادهم وجميع

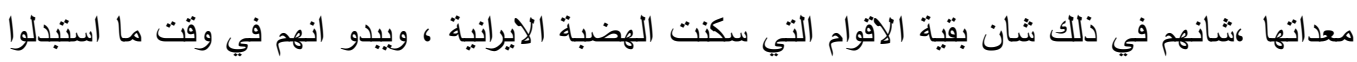

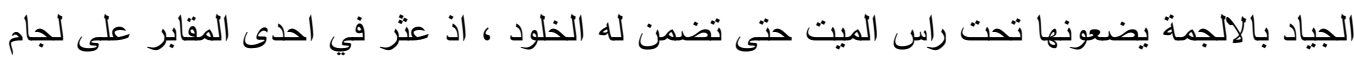

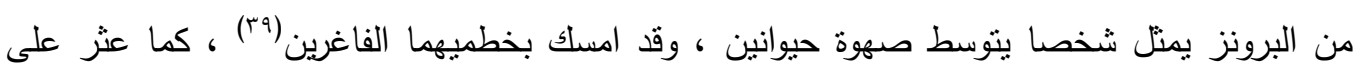

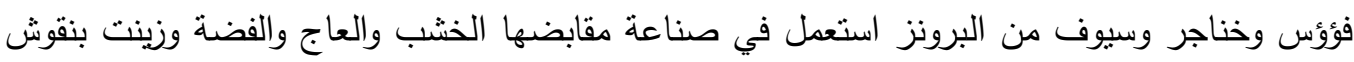

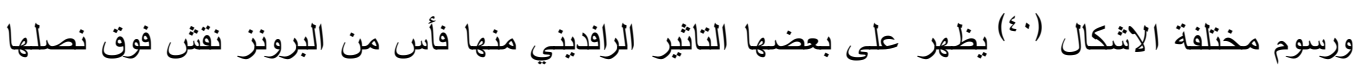

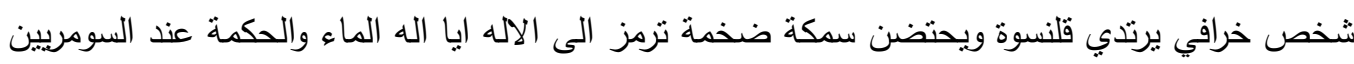

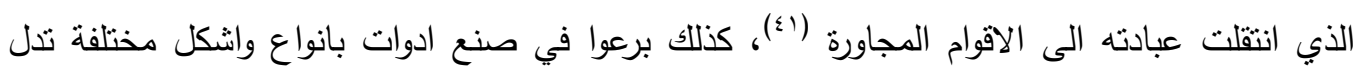

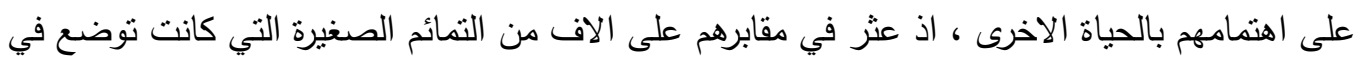

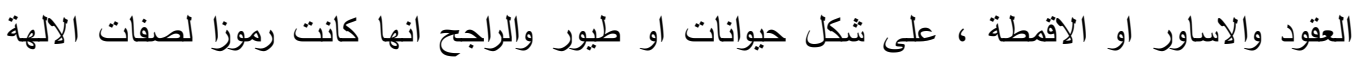

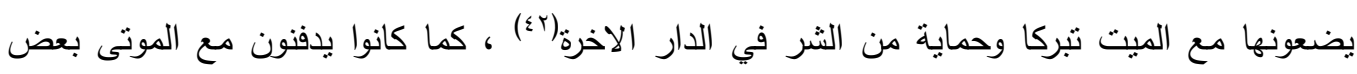

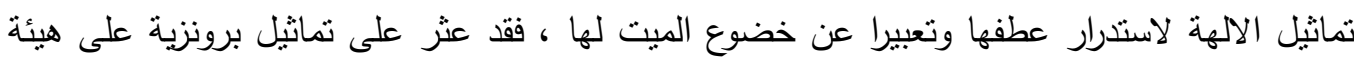

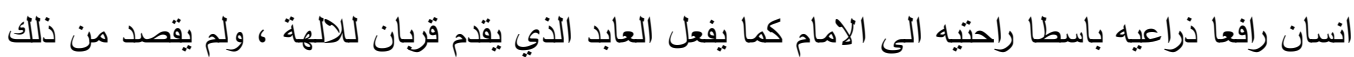




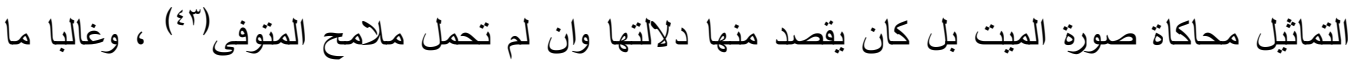

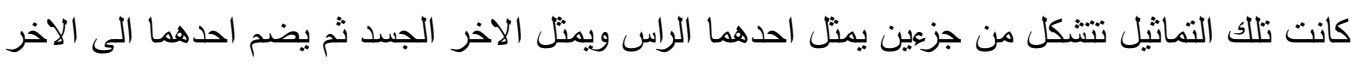

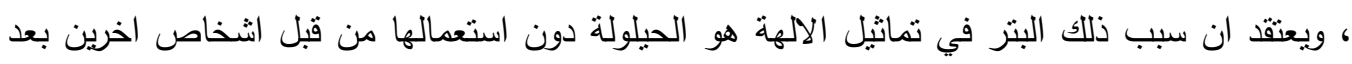

$$
\text { موت صاحبها (๕£). }
$$

ومن الاثتياء التي عثر عليها في معبد سورخ دوم(Sorkh Dum) في منطقة لوريستان دبابيس وضعت

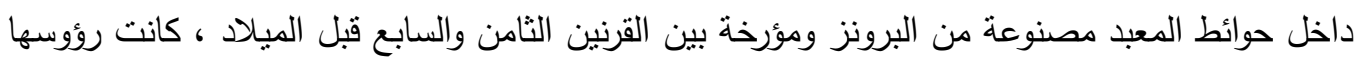

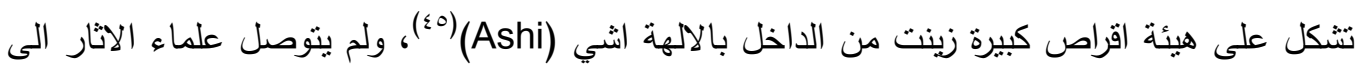

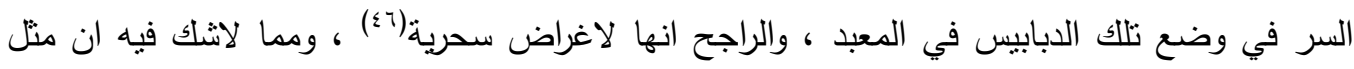

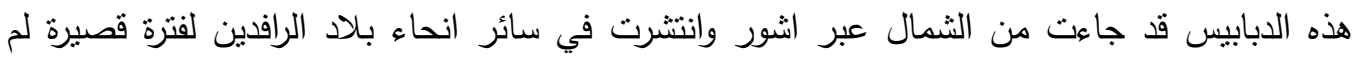

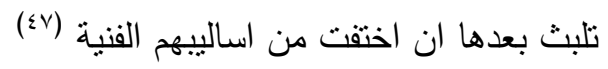

الى جانب ناثرهم بالفن الرافيني ناثر الكيمريين بالفن الأورارتي فقد عثر في معبد سورخ دوم على دروع نذرية مستديرة الشكل زين وسطها برأس آدمي ، واصل صناعة بأنس التك الدروع اورارتي فيذكر انهم كانوا

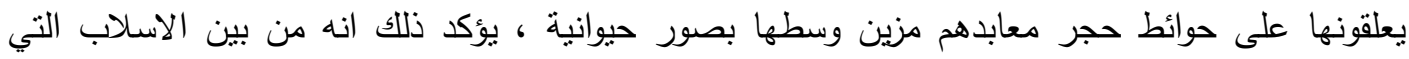

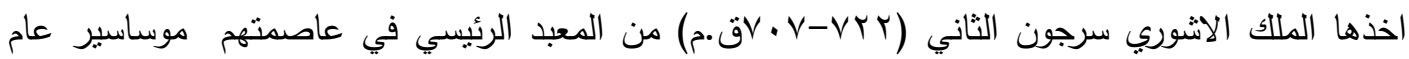

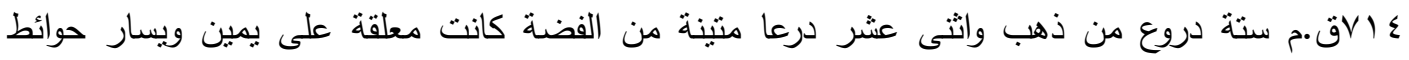
المعبد ، ومما ينبغي ناكيده ان تزيين وسط تلك الدروع بصور ادمية لم يكن اختراعا يونانيا ، وانما هو ايراني

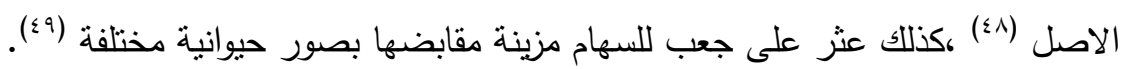
اما الحلي فقد ابدع الفنان اللوريستاني في صناعة الاساور من البرونز والحديد والذهب، وصناعة

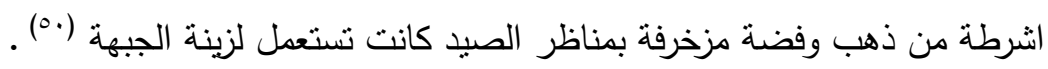

يتضح مما تقدم اعلاه ان اهم ما امتاز به الكيميريين هو فنهم وهو فن متقدما جدا في صناعة

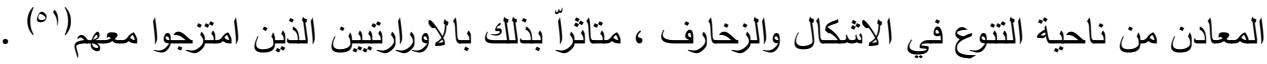


تزامنت هجرة الاسكيثيين الى اسيا الغربية مع هجرة الكيمريين في القرن الثنامن قبل الميلاد ، ودخلوا

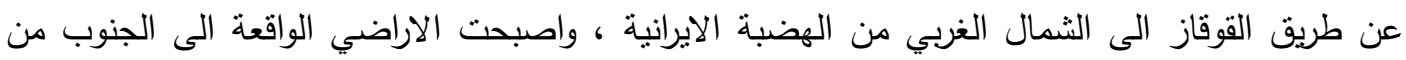

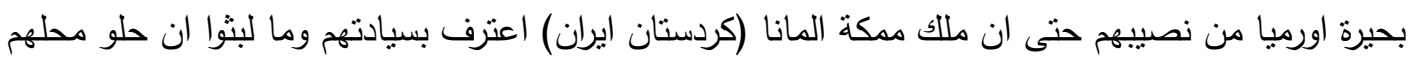

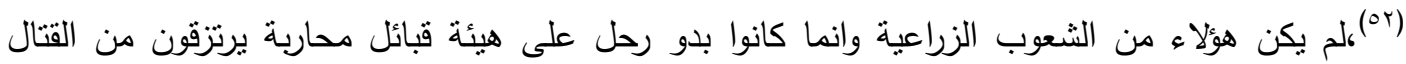

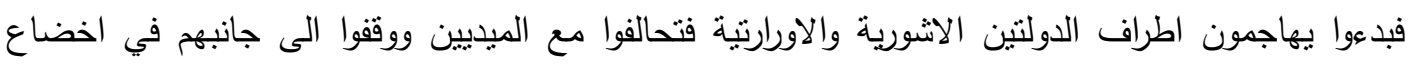

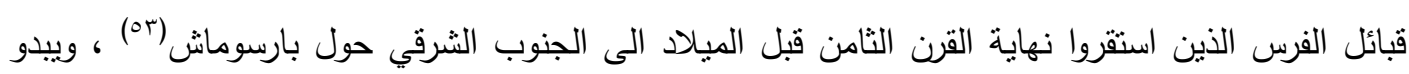

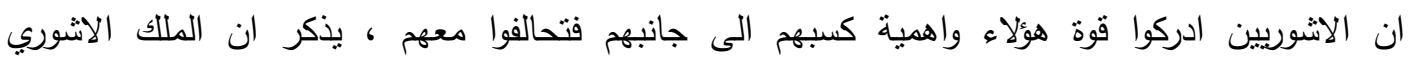

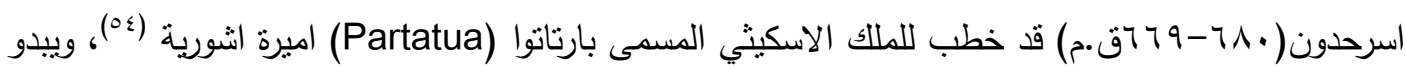
ان ذلك التحالف شجعهم على التوسع فاخذوا يشنون الغارات هنا وهناك ، فغزوا الاورارتيين ثم الكيمريين في

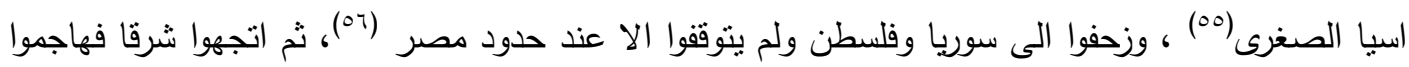

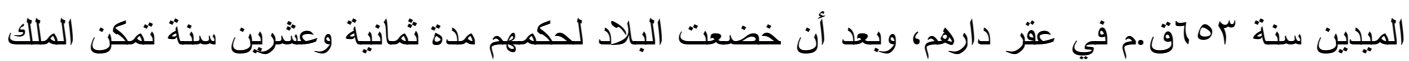

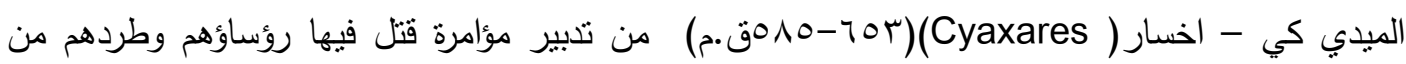

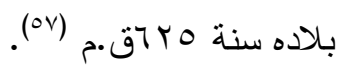

ما خلفه الاسكيثين من مظاهر حضارية تم التعرف عليها من مقتتياتهم التي عثر عليها في مقابرهم

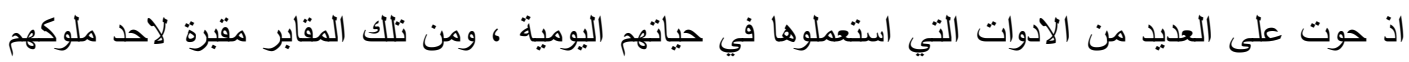

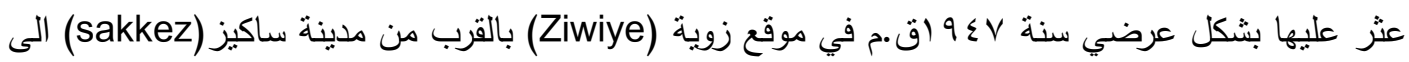
الجنوب من بحيرة اورميا ، عثر فيها على كنز حوى على مجموعة كبيرة من الادوات الذهبية والبرونزية

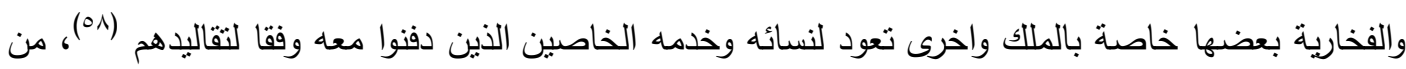

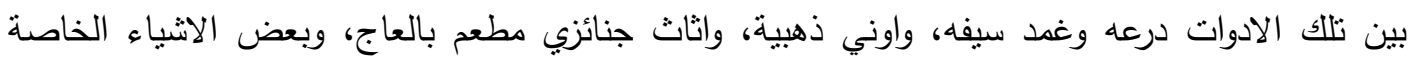

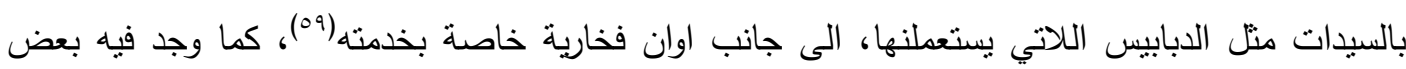

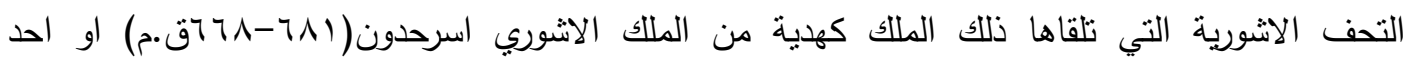

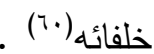


ومن خلال دراسة التي اجراها علماء الاثار على تلك المخلفات تبين ان هناك ناثيرات شرقية واضحة انورية واورارتية ، فهناك شبه كبير بين المنحوتات الموجودة على تابوت زوية وتلك التي تزين قصر

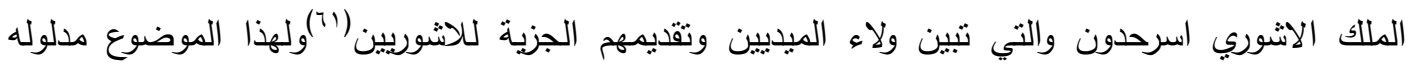
السياسي فاحد الملوك الاسكيثين اعتلى عرش ميديا سنة به بق.م واخذ يتقبل ولاء الميديين وتقديمه للجزية له بدلاً من الملك الاثتوري(rآ)، ويدل دلالة قاطعة على ناثر الاسكيثيين بالفن الرافديني .

ولاقامة الاسكيثيين عبر القوقاز الى الثرق والى الثمال الثرقي لحدود الاورارتو جعلها على صلة مباثرة بهذه المملكة وحضارتها، وهذا ما اكدته محتويات مقبرة زوية ايضا اذ عثر فيها على صدرية ذهبية

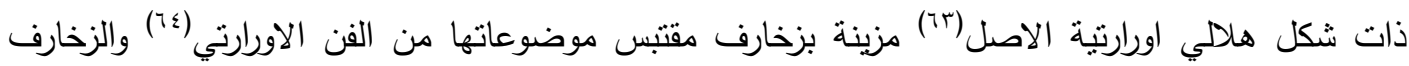

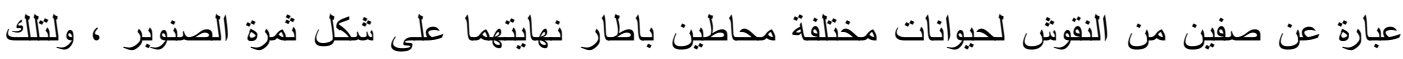
الاشكال من الحيوانات مغزى رمزي يضمن لمرتديها الحماية والقواية من عوادي الزمن (70).

كذللك توجد رابطة بين الفن الاسكيثي واللوريستاني ،ققد عثر في مقبرة زوية على لوحة من الذهب

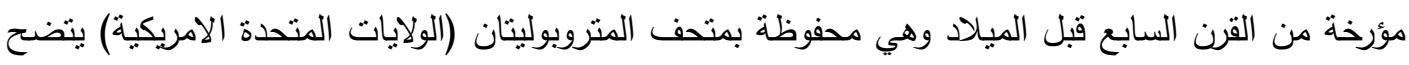

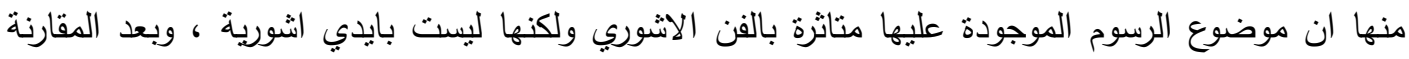

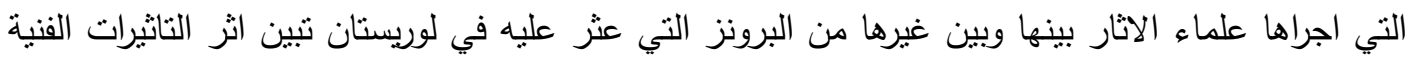

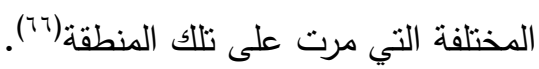

اما اواني الثرب سواء تلاك المصنوعة من الذهب والبروزنز والفخار المطلي بالميناء او العادي التي

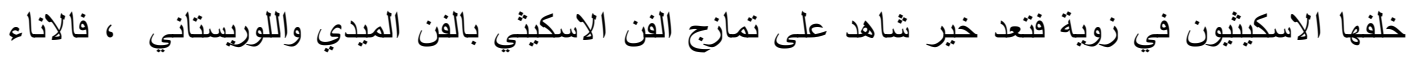

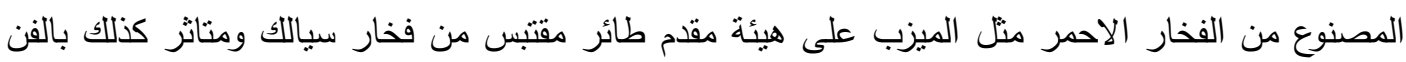

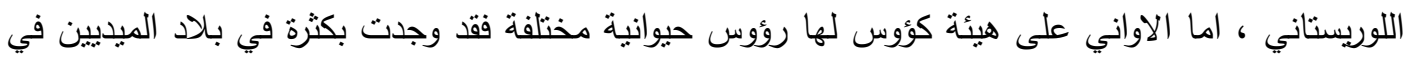

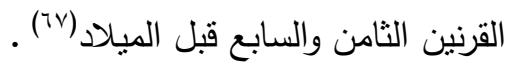

ومما يجدر ذكره ان الاناء الذي على شكل بطة كان معروفا منذ الالف الرابع قبل الميلاد في صناعة الفخار في سوسة ، وكذلك معروف في مصر الفرعونية ، اما الاناء الذي تتنهي قاعدته براس كبش فمعروف

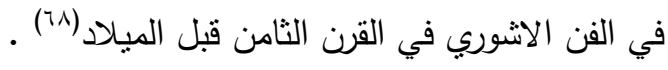




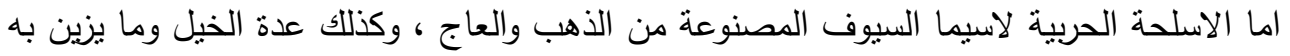
رؤوسها التي عثر عليها في مقبرة زوية فقد مكنت عماء الاثار من معرفة التقاليد الاسكيثية في صباغة

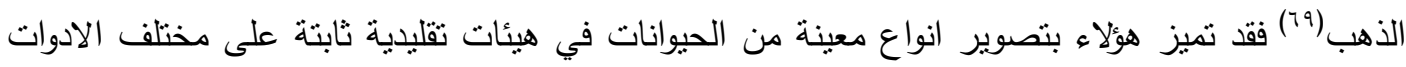

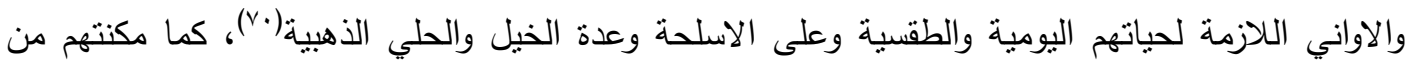
معرفة مدى تاثر الفن الايراني بالفن الاورارتي في تتكيل العاج ونحته ، فالكرة الذهبية التي تمثل مقبض التص

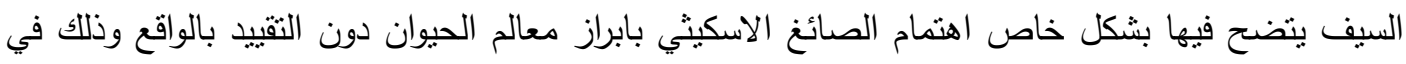

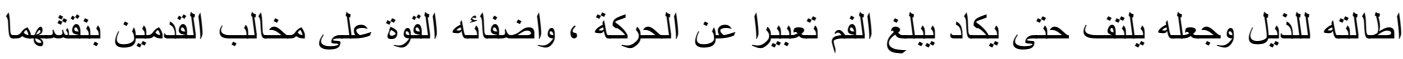
مطويتين تحت الراس والجسد(1)

مما تقدم يتضح ان الفنون الثرقية شكلت عناصر اساسية في الفن الاسكيثي الذي استبلوا العظام والخشب والحديد والبرونز بمعادن ثيينة ولاسيما الذهب وان الكثرة الغالبة في صناعة الحلي الذهبية توكد ان هذه

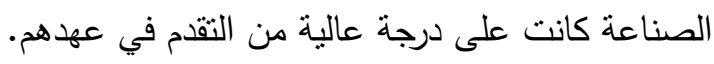

(Medians) r- الميديون

دخل الميديون إلى الهضبة الإيرانية في مطلع الألف الأول قبل الميلاد(VY) ، واستقروا في القسم

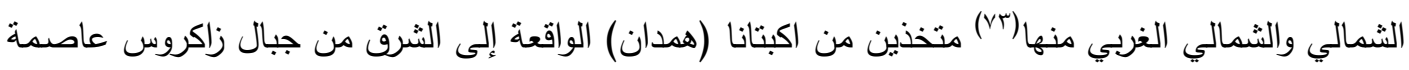

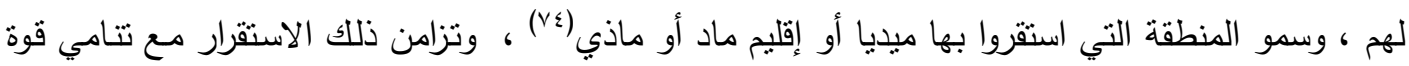

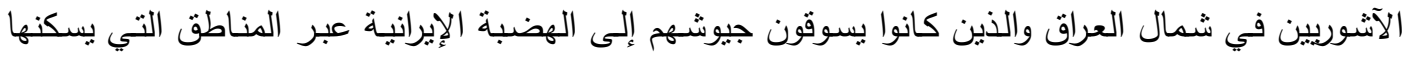

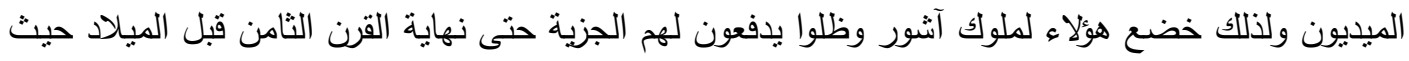

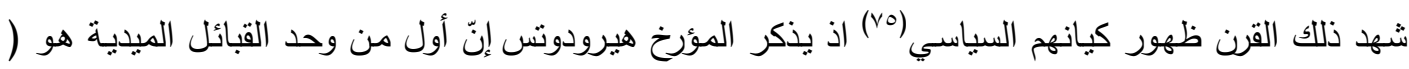

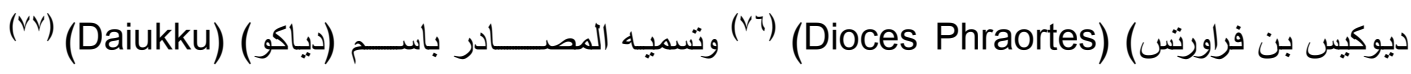

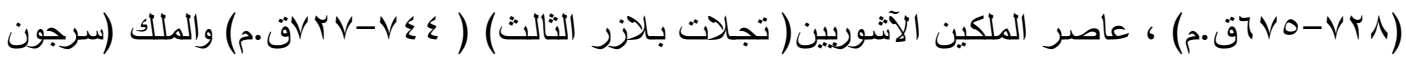

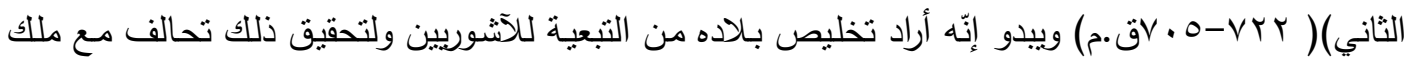

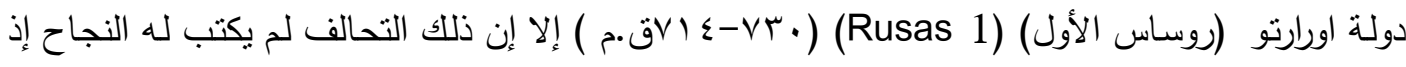

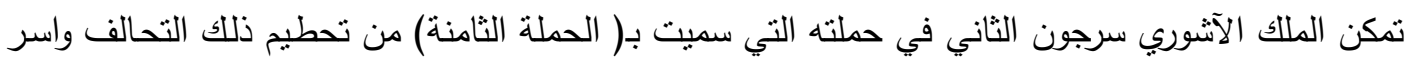




\section{العــــــد الثامن وإلعشرون}

مجلــــة كليــــة التربيـــة

الملك الميدي دياكو سنة 1 المقم ونفاه مـع أسرته إلى سوريا وكان من نتيجة ذلك إنّه أخضع الميديين

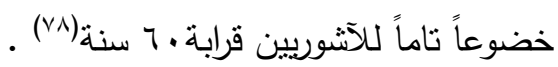

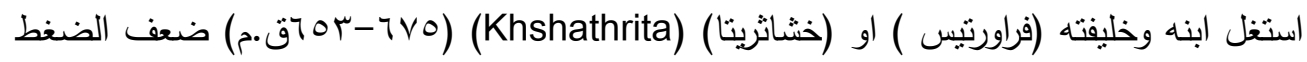

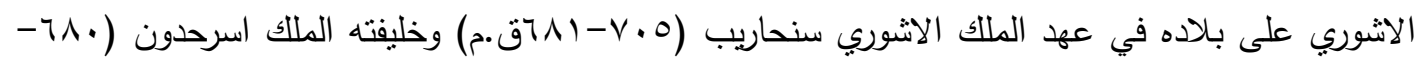

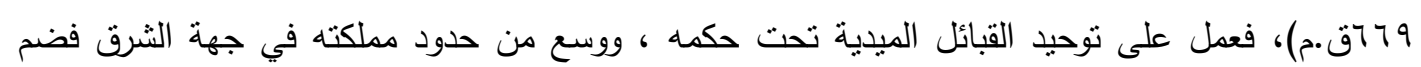

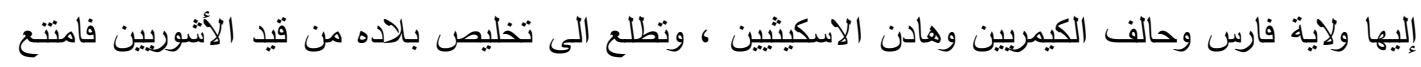

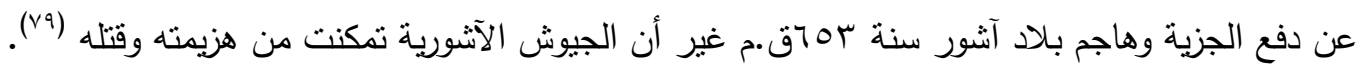

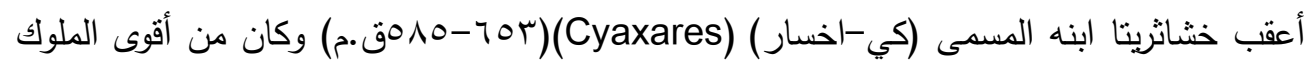

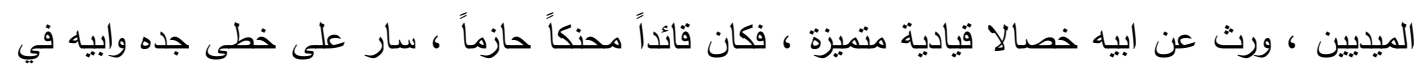

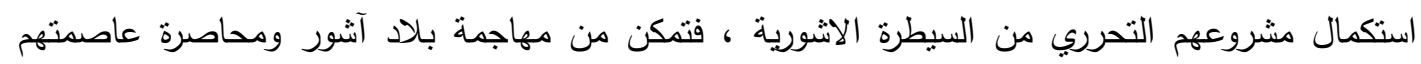

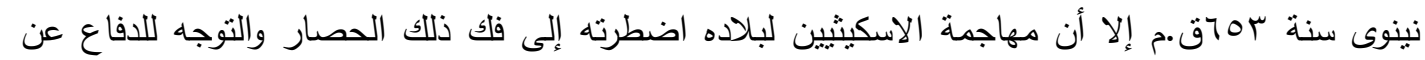

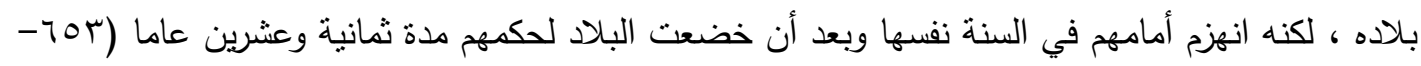

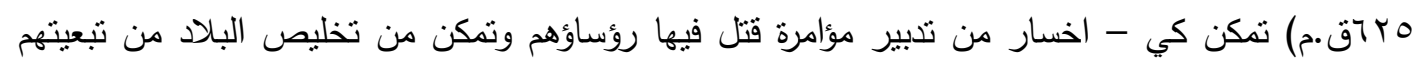

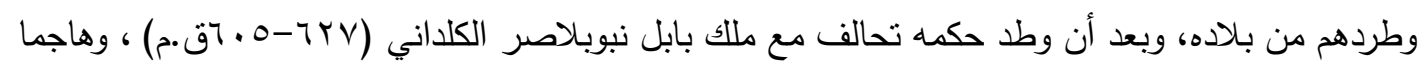

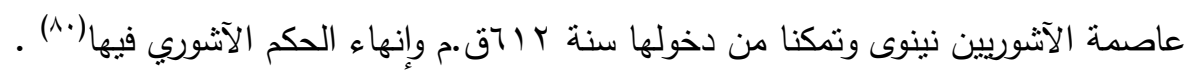

بعد سقوط الدولة الاتشورية وجه الميديون نثاطهم باتجاه اسيا الصغرى فدخلوا في صراع مع اقوى

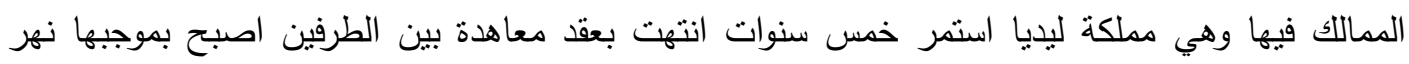

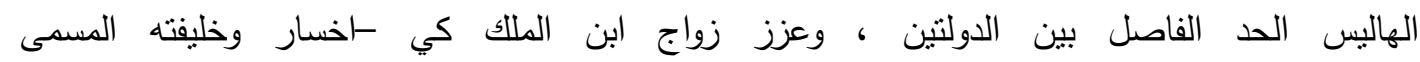

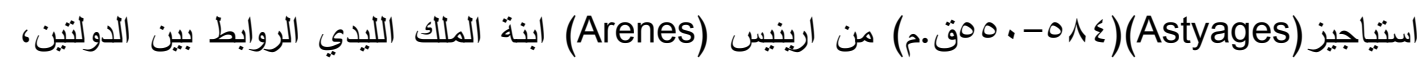

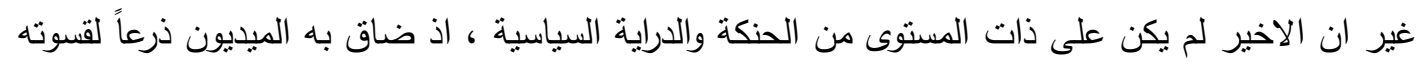

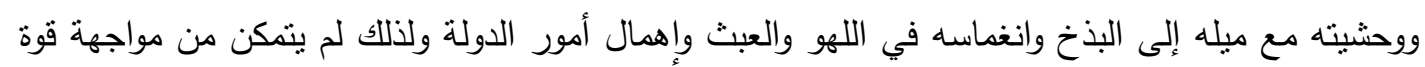

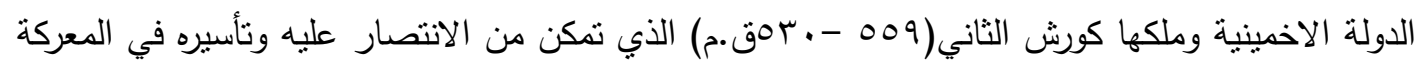
التي جرت بينهما بالقرب من بازركادة سنة ـ00مقهم وضعا بذلك نهاية للدولة الميدية(1). 
وفيما يتعلق بالثقافة والحضارة الميدية ، فهناك من المؤرخين من يرى ان الدولة الميدية لم يكن لها

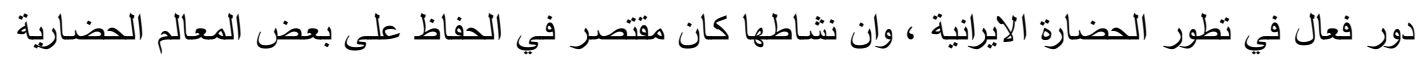

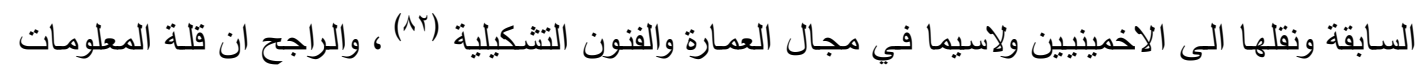
عن الحضارة الميدية سببه الفرس الاخمينيين الذين اسقطوا الامبراطورية الميدية، فانتقال الحكم من الميديين

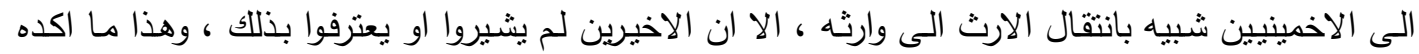

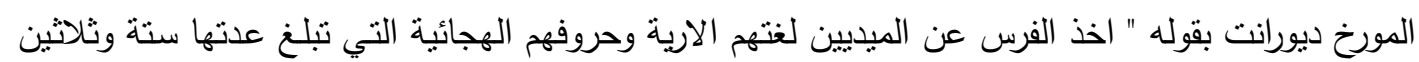
، وهم الذين جعلوا الفرس بستبدلون في الكتابة الرق والاقلام بالواح الطين ، ويستخدمون في العمارة العدد العدانه

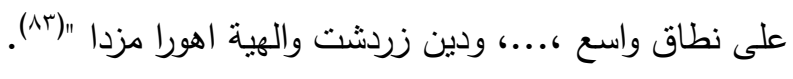

ففي مجال اللغة نجد صدى لذلك الاقتباس عند المؤرخ الروسي دياكونوف الذي اكد على ان اللغة

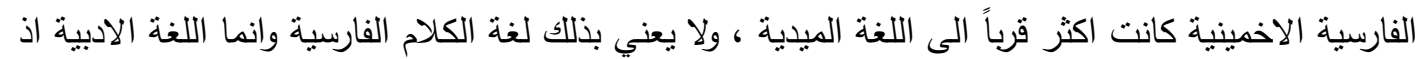

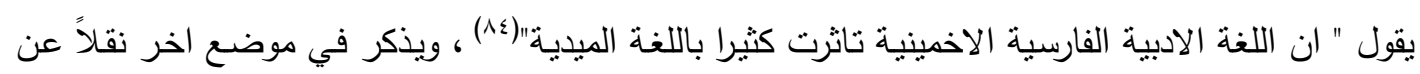

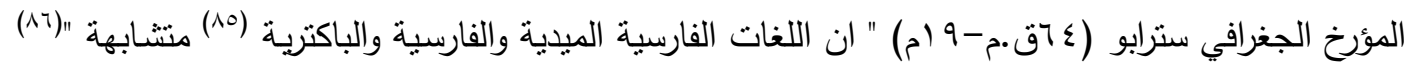
، اما عن اصل لغة الميديين فان المؤرخ هارفي بورتر يقول " ولغة الماديين من اللغات الاريانية ابي الهندية

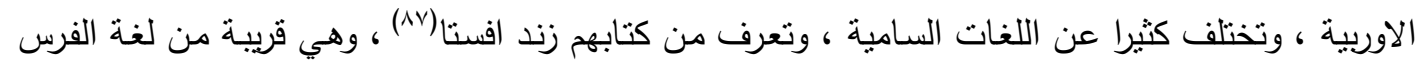
فلا تختلف عنها الا قليلا وكل منهما يثبه لغة السنسكريت وهي لغة الهند القديمة "(A^).

اما عن الكتابة فيذكر المؤرخ دياكونوف انها كانت موجودة على ارض ميديا في الالف الاول قبل

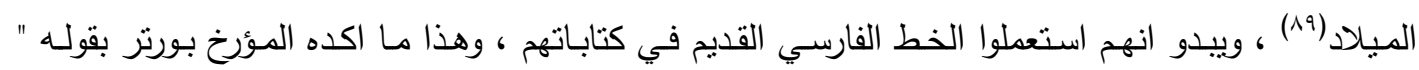
الارجح انهم استعطلوا الكتابة وكان خطهم السفيني (المسماري او الفارسي القديم) كالاشورين ، وحروفهم سبعة ودانة

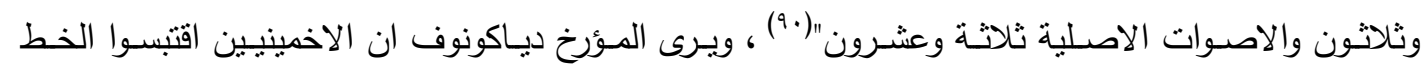

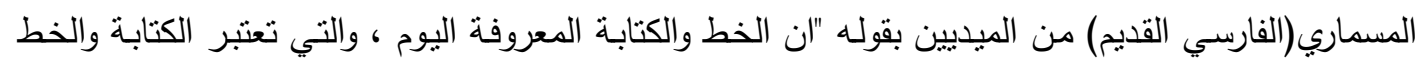

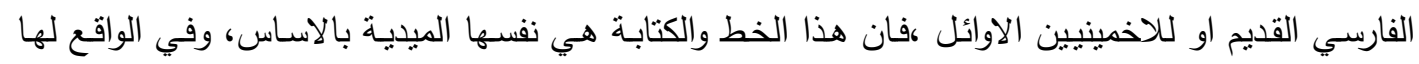

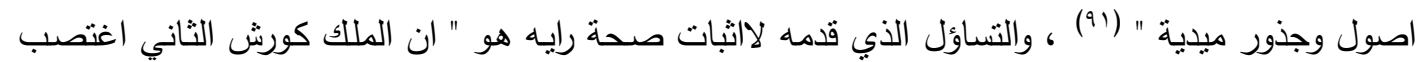

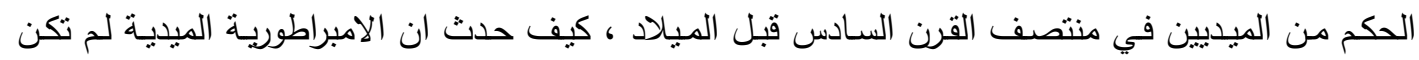


تمنلك خطا وكتابة خاصة بها ، بينما البارسيون الذين كانوا تابعين الى هذه الامبراطورية كانوا بملكون خطا

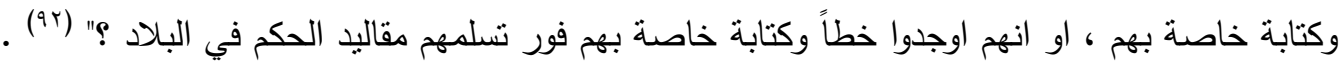

والواقع ان مجموعة الاثار الثمينة التي اطلق عليها اسم كنز جيحون (the Oxus Treasure)

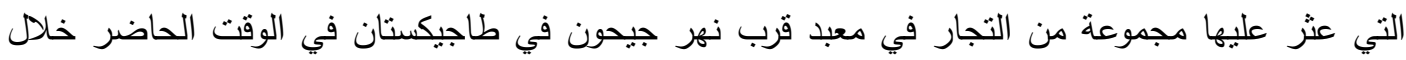

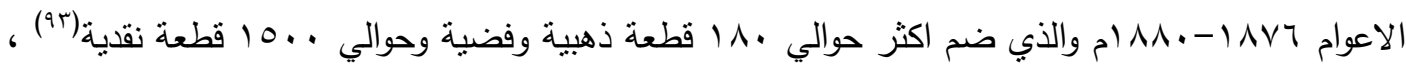

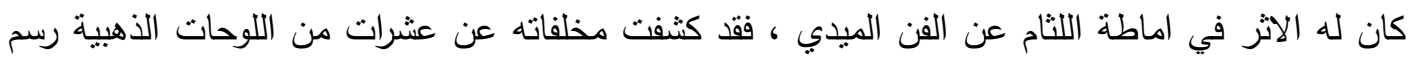

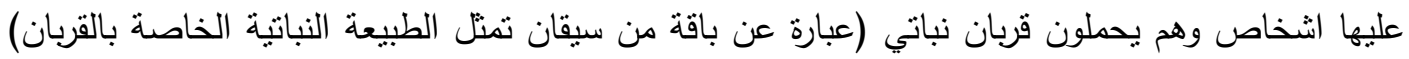

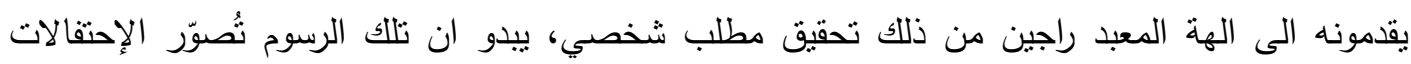

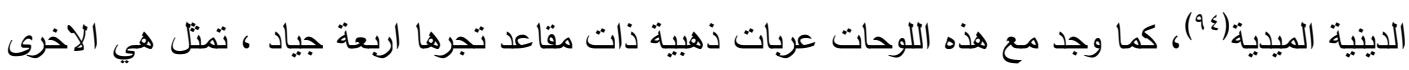
احد النذور المقدمة للالهة (90).

مكنت الدراسة الدقيقة لتلك اللوحات علماء الاثار من التعرف على ملابس الميديين التي هي عبارة

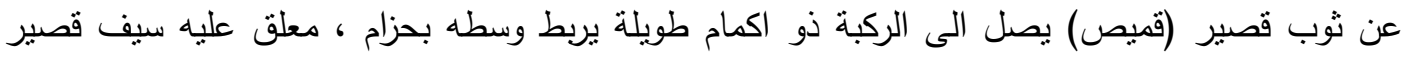

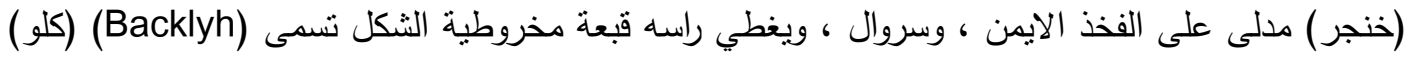

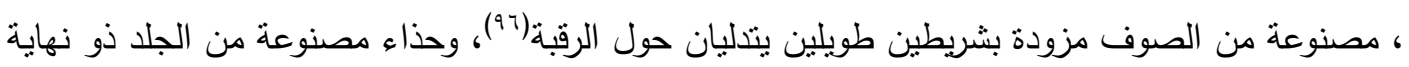

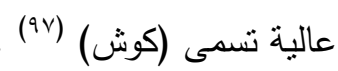

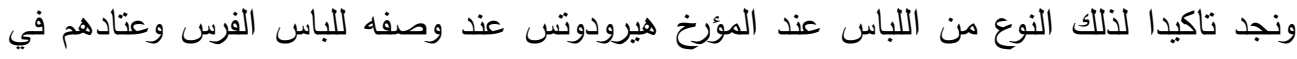

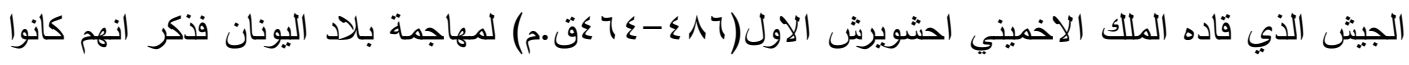

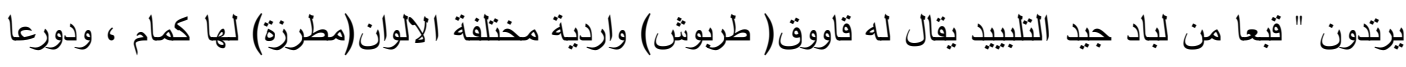

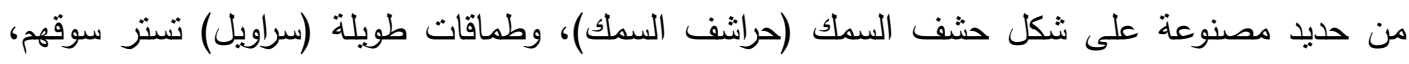

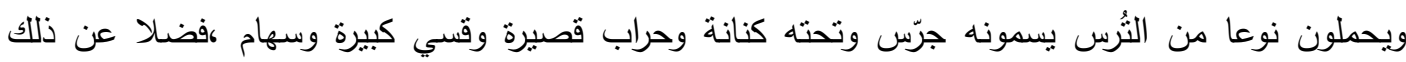

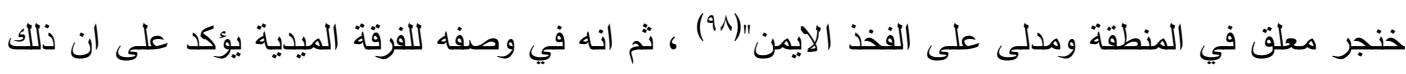

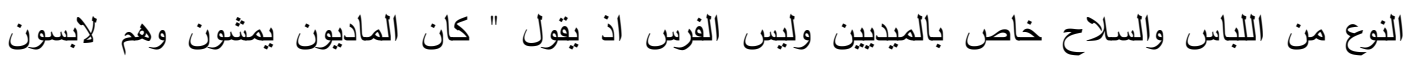

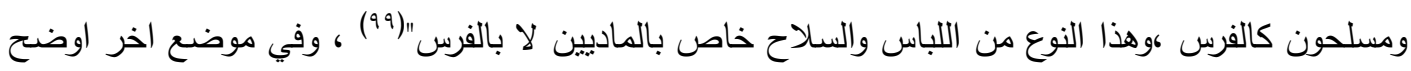


هيرودوتس السبب الذي دفع الفرس (الاخمينيين ) الى ارتداء الزي الميدي بقوله" ان الفرس كانوا يلبسون الزي

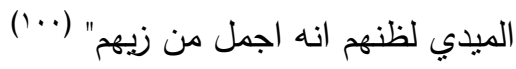

وبطبيعة الحال فان ملابس العامة تختلف عن ملابس الملوك والطبقة الارستقراطية فيذكر المؤرخ دياكونوف بان ملابس الفرسان كانت عبارة عن ثوب طويل ذو اكمام طويلة، ربط وسطه بحزام ، علق به

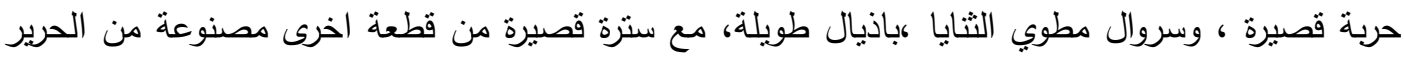

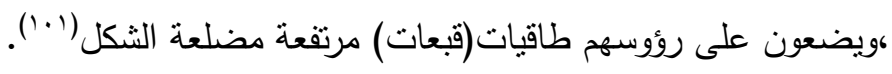

ومما يجدر الاشارة اليه وفي سياق ذكر الفرسان فان عماد سلاحهم هي الخيول ، وهي اكثر ثروة

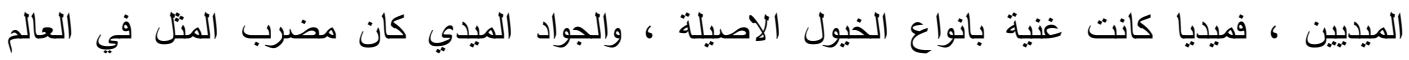

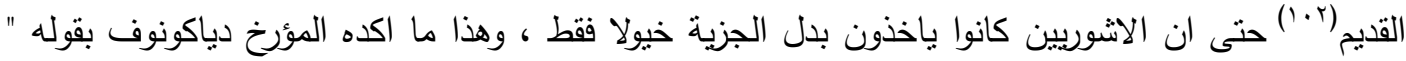
الخيول التي كانت تربّى في ارض ميديا تُعنبر مشهورة جدا ، وكان الاشتوريون ياخذون بدل الضرائب والجزية

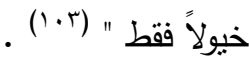

وابدع الميديون في صنع العديد من اون الثرب الذهبية والمشغولات المعدنية التي تدل على مهارة

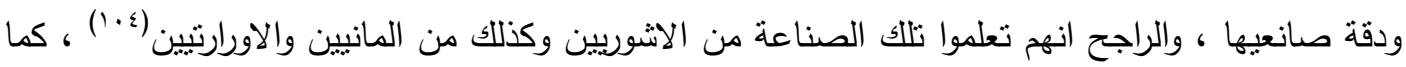
يتضح فيها التاثير الاسكيثي من خلال رسم الحيونات باسلوب واقعي ، وخير شاهد على ذلك كاس كلاردشت

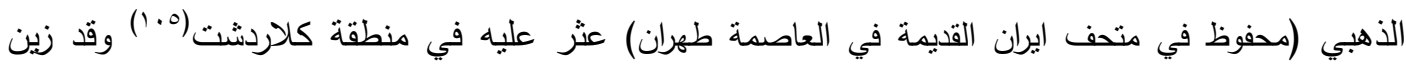

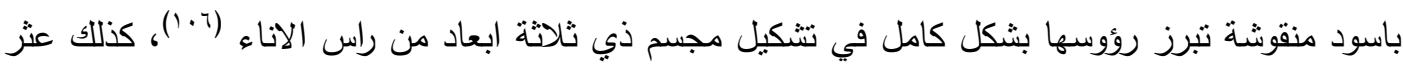

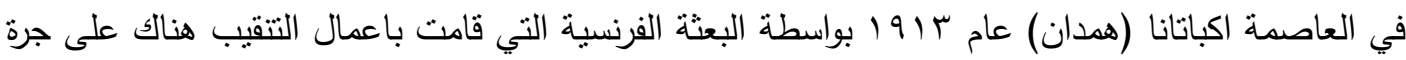
من البرونز لها ميزاب طويل ، مثبت في بطن الاناء بواسطة سبع مسامير لها رؤوس شبه كروية ، ولها يد

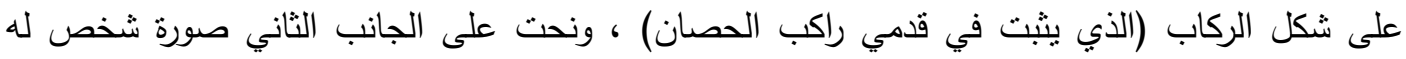

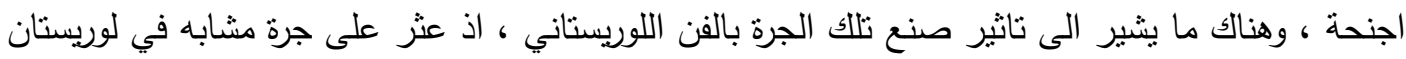

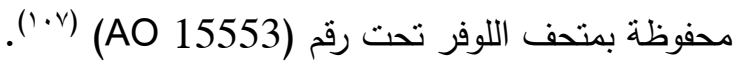

كذلك برع الميديين في صناعة البسط والسجاد وصناعة النسيج وتزينه بزخارف منتوعة(م · ) ،وبيدو ان حاجتهم الى الدفء من برد جبالهم القارس وتغطية ارضيات غرفهم هو الذي دفعهم الى استخدام قدراتهم 


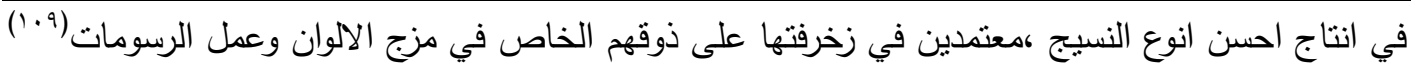

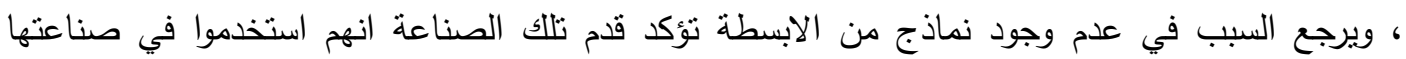

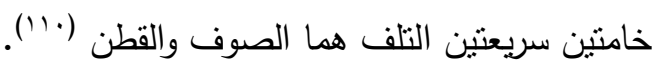

اما العمارة الميدية فتحدثا عنها القبور المنحوتة في الصخر ومنها مقابر كيزكابان (Qyzqapan) في كهف شهرزور الواقع جنوب شرق مدينة السليمانية جنوب كردستان، وهذه المقبرة بنيت على ارتفاع V كم من سطح الجبل وهي تثببه مقابر الاسكيثيين ، اذ تتكون من رواق خارجي ذي اعمدة مستديرة ومن ثلاث

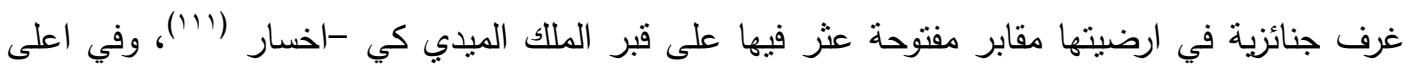

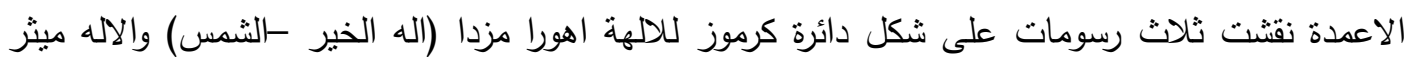

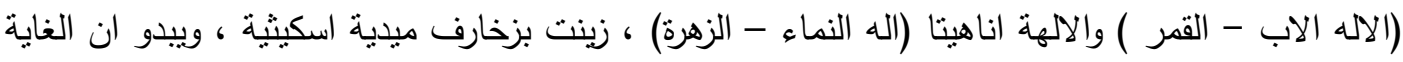
من نقش تماثيل لتلك الالهة هو لاستدرار عطفها على المتوفى ، وفوق باب مدخل الغرفة نحتت لوحة افقية

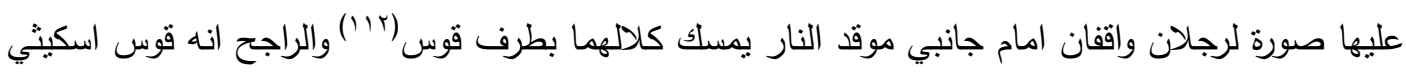

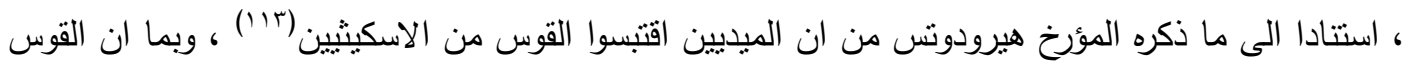

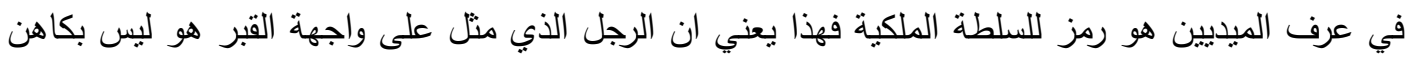

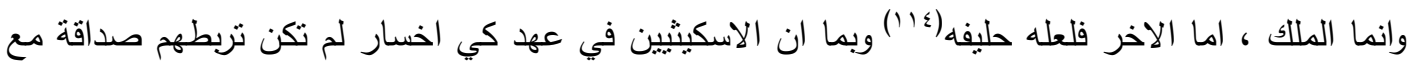
الميديين فهذا يعني ان تلك اللوحة تتحدث عن تحالف ميدي بابلي تسبب في اسقاط نينوى .

اما مقبرة ساكافاند على سفح جبال سورداش في منطقة دوكان فقد عثر فيها على قبر الملك الميدي استياجيز ، وقد نم تزين باب مدخل حجرة الدفن بنقش ذو اسلوب محلي نتببه وقفة الثخصية الرئيسة التي نقشت عليه وقفة العابد اللوريستاني وقد رفع ذراعبه مولولاً بالحركة المالوفة عن تماثيل لوريستان الصغيرة

وفيما يتعلق بالعاصمة الميدية هانجمانانا (Hangmatanna) او اكبانانا (هدان) عندما اصبحت

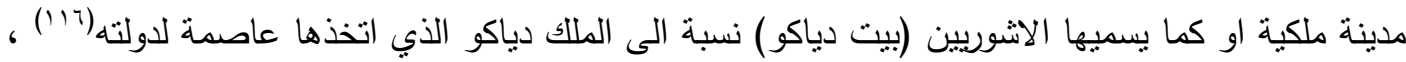

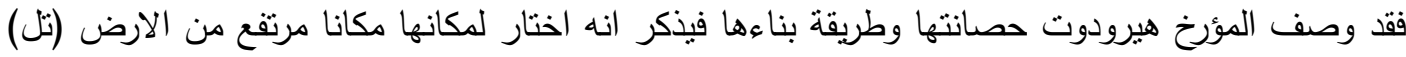
وحصنها تحصينا قويا بسبعة اسوار دائرية ، كل منها اعلى مما خارجه ، فصارت كانها درجات، وشرفات كل من تلك الاسوار بنيت باحجار ذت لون مخصوص ، فشرفات السور الاول بنيت بحجارة بيضاء ، وشرفات 
الالذي فوقه وهو السور الثاني سوداء ، وشرفات السور الثالث قرمزية اللون ، والرابع زرقاء اللون والخامس

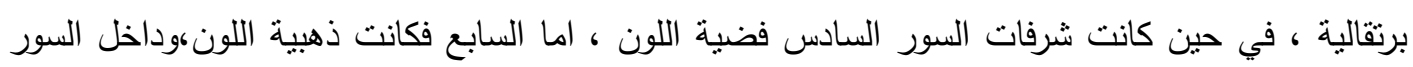

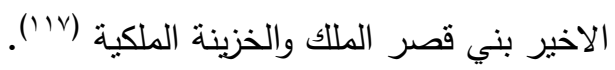

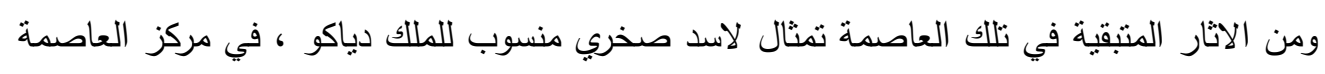

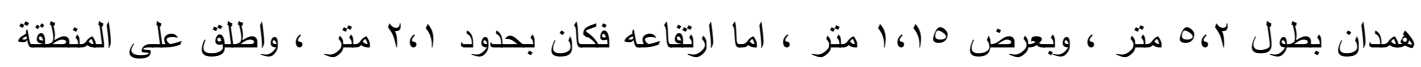

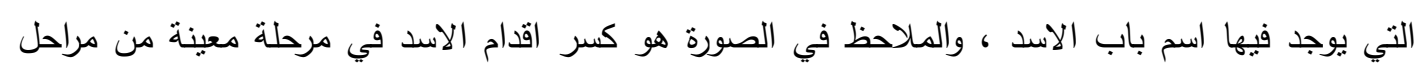

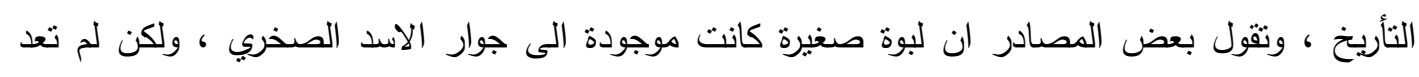
موجودة (111).

وتصف المصادر ضخامة قصر الملك ومظاهر التزف فيه ، فقيل عنه ان قصره يعجز عن وصفه اللسان مساحته ثلثي ميل وفيه اروقة واعددة كثيرة وسطحه مغطى بالفضة بدلا من القرميد وجوائزه وروافده

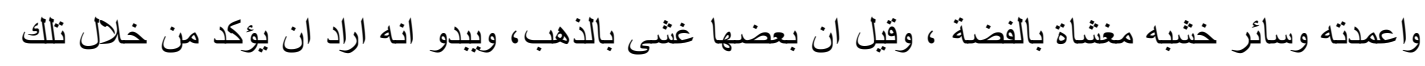

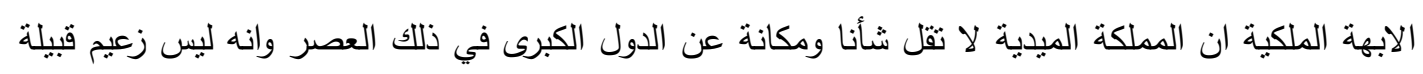

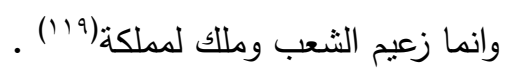




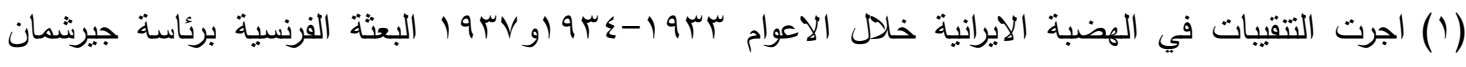

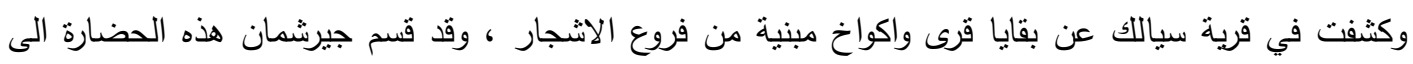

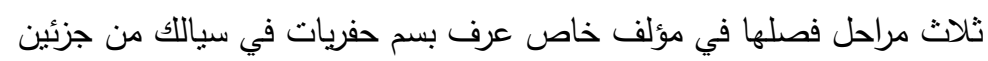

Ghirshman,Roman,Fouilles de Sialk pres de Kashan 1933-1937,in Journal des savants,Avril-juin,1941p.p ,64-75.

(2) Ibid,p.66.

(3) Ghirshman ,Roman, Iran from the Earliest times to the Islamic conquest, London,1954,p.29

(4) Samani,Rouzbeh,Aspects of Achaemenid Art A look into the native and the foreign ,Leiden,2009,p.25.

(5) Childe,V.Gordon,New Light on the Most Ancient East,London and New York,1952,p.192.

الناظوري ، رشيد ، دراسات في بعض معالم تاريخ وحضارة منطقة الثرق الادنى القديم وخاصة في مصر وبلاد

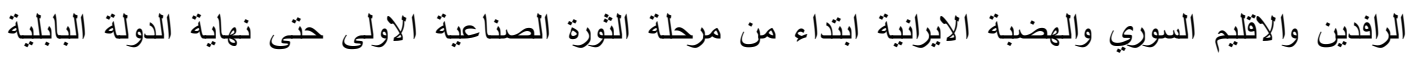

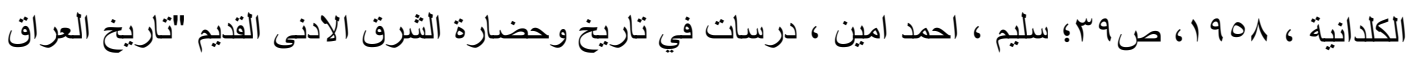

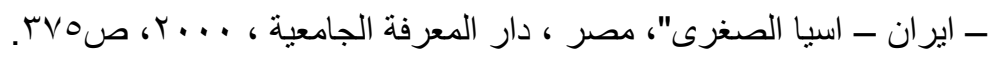

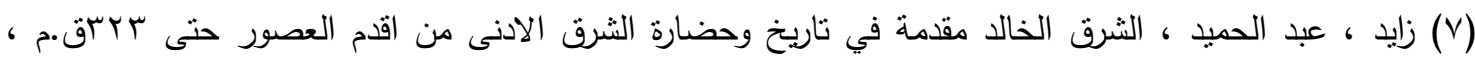

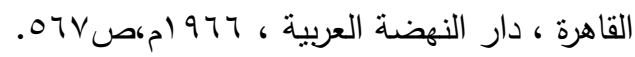

(8) Ghirshman , Iran,p.36;

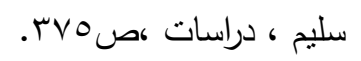

(9) ان موقع الهضبة الايرانية المتوسط بين منطقة الاحراش في اواسط اسيا وبين سهول غرب اسيا اكسبها اهمية

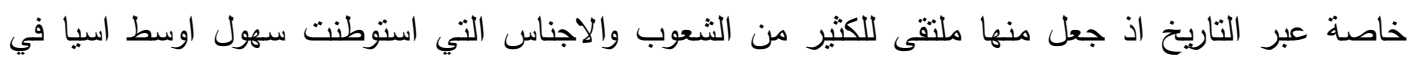

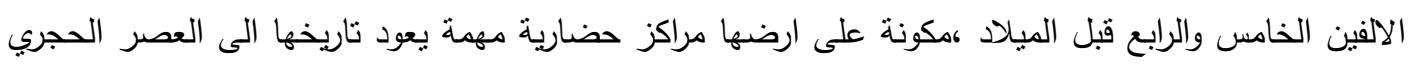

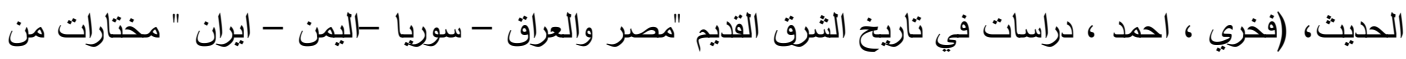

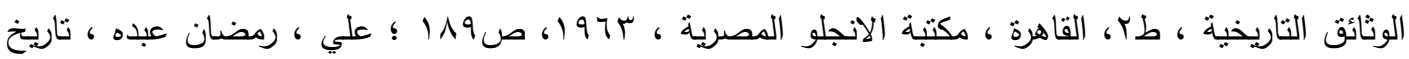

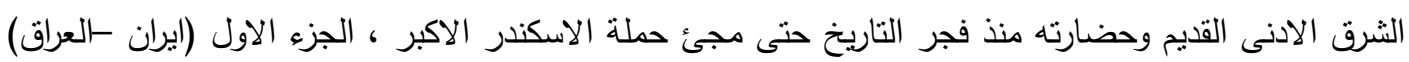

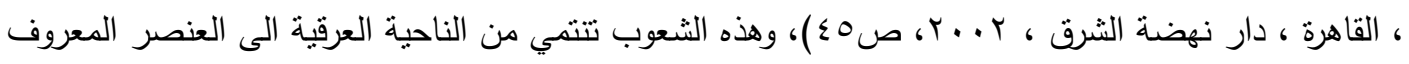

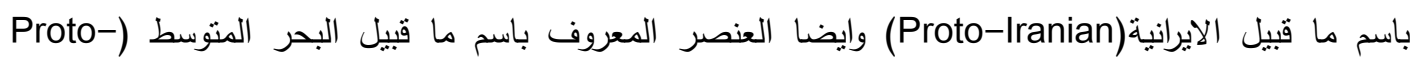


(Aediterenean

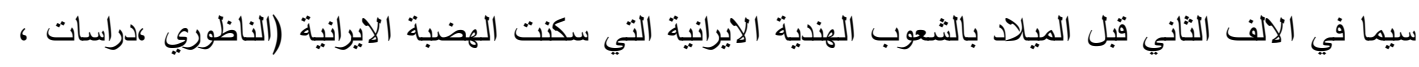
ص. ص. ( )

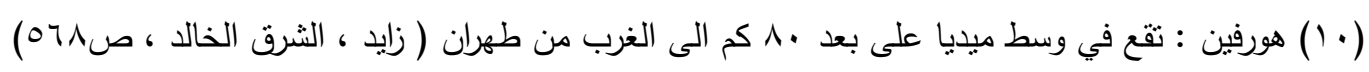

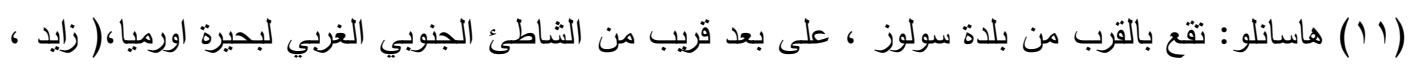

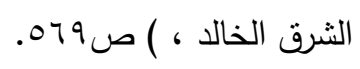

(r r) املاش : موقعها جنوب غرب بحر قزوين (عكاشة، ثروت ، الفن الفارسي القديم ، ط9، القاهرة ، المجلس

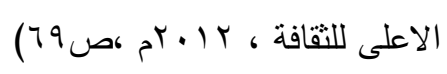

(13)Ghirshman , Iran from,p.36;

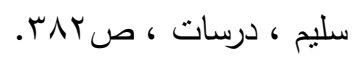

(ع 1) ظهر الانتاج الحضاري في المرحلة الحضارية الثالثة لعصور ما قبل التاريخ في الهضبة الايرانية في العديد من

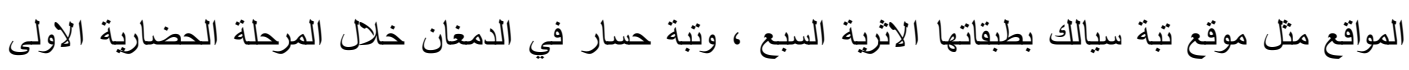

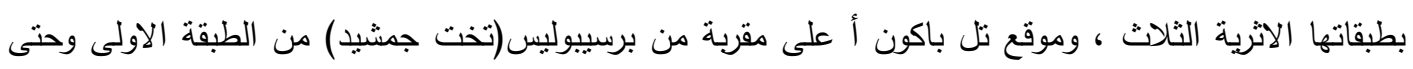

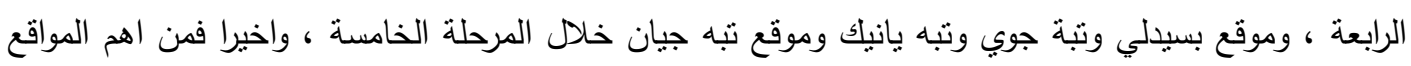

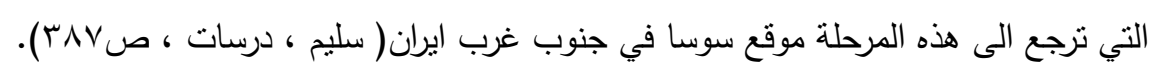

(15) Iran from ,p.40.

(16)Ibid,p.40;Gobineau,J.A., The World of the Persians , Geneve,1971,p.130.

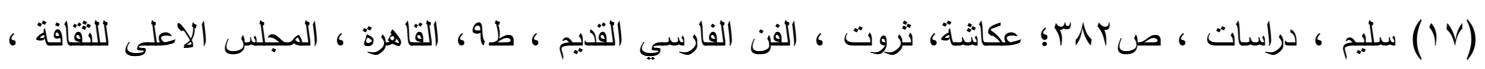

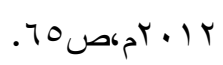

(18) Ghirshman , Iran,p. 41;

$$
\begin{aligned}
& \text { الناظوري ، دراسات ، صז؟ء. }
\end{aligned}
$$

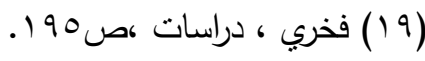

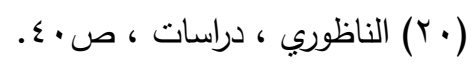

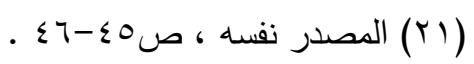

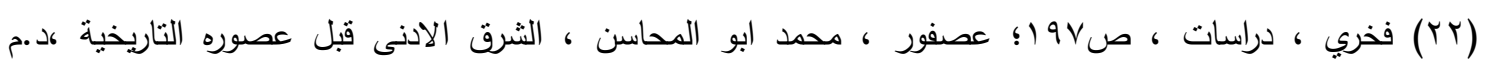

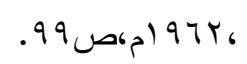

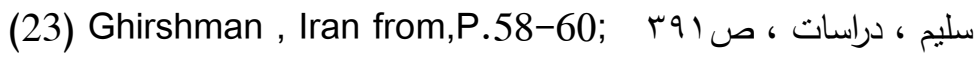




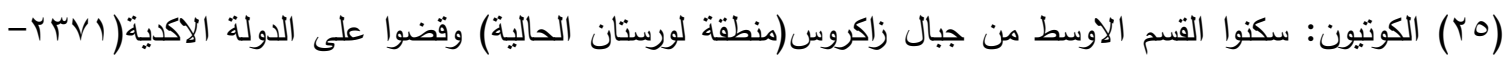

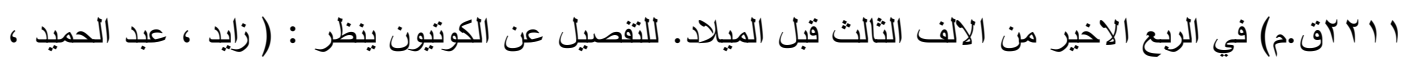

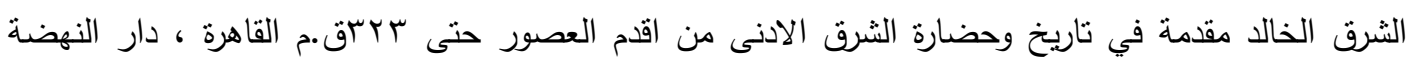

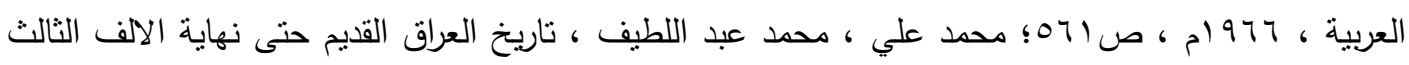

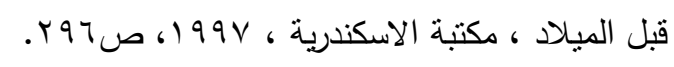

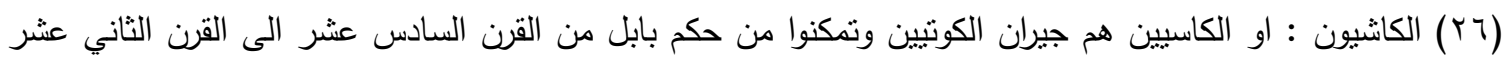

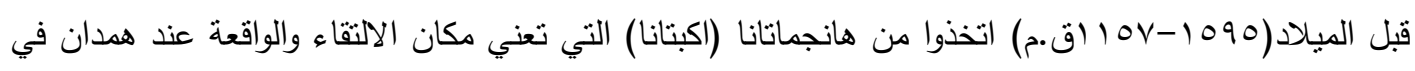

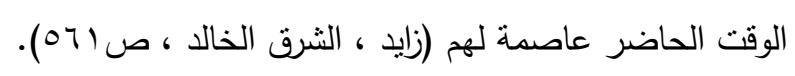
اللولبيون: كانون يسكنون القسم الثمالي من مرتفعات زاكروس وامتد نفوذهم حتى بحيرة اورميا وفي ايام مملكة

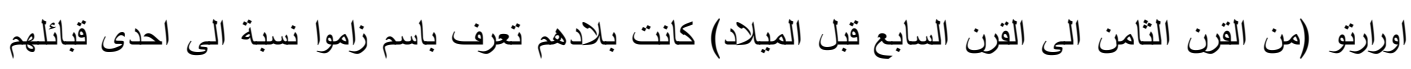

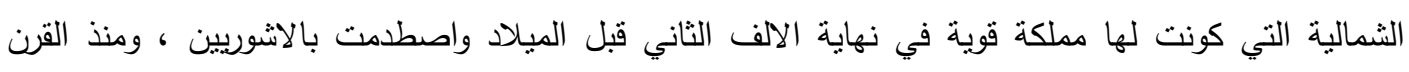

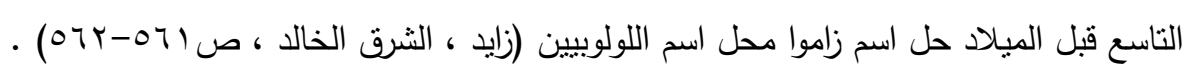

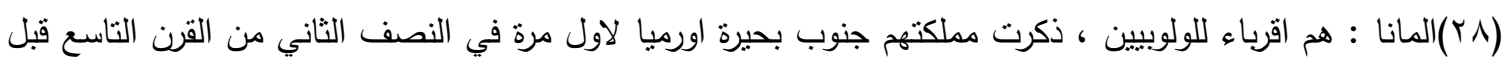

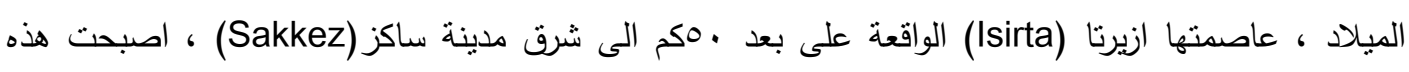

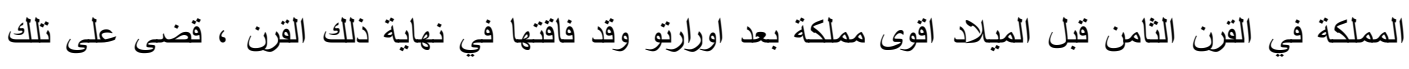

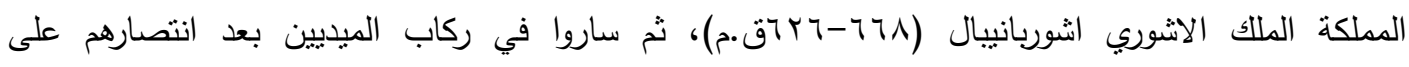

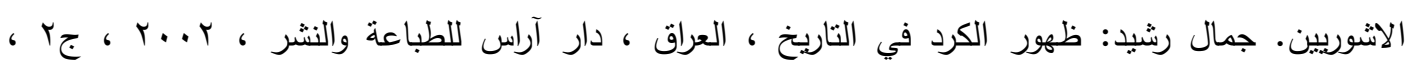

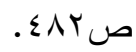

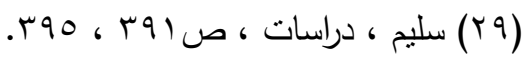

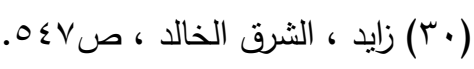

(آ⿱ ضدت الاقوام الارية الايرانية قبائل عدة منهم الاسكيثيين والكمريين والميديين والفرس والبارثيين والباكتريين (الهل

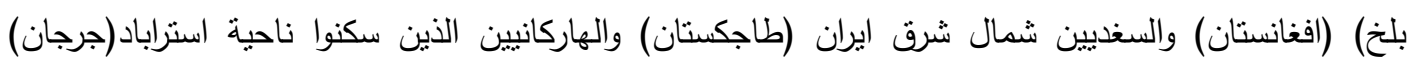

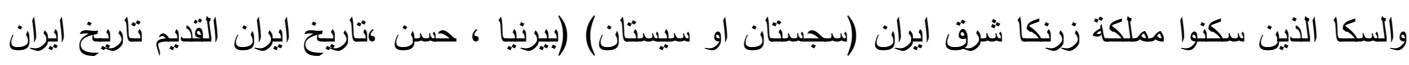

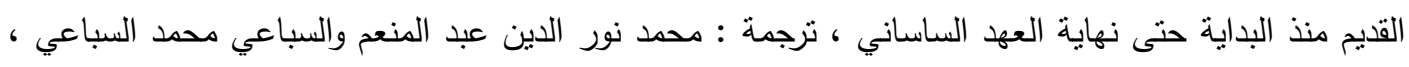

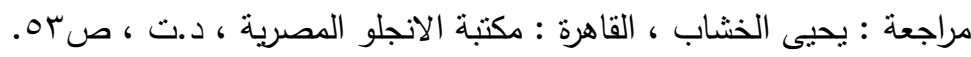




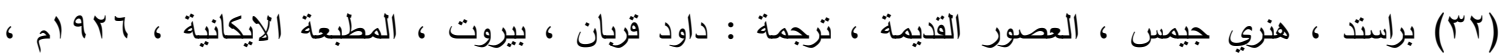

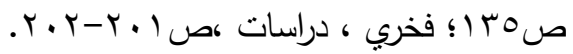

(Tr) اورارثو : من الدول القوية التي حكت أرمينية قبل الأرمن ، تمركزت في النصف الثاني من القرن التاسع قبل

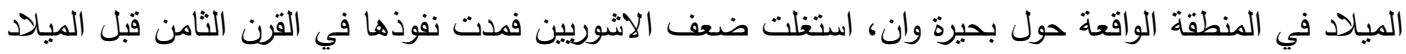

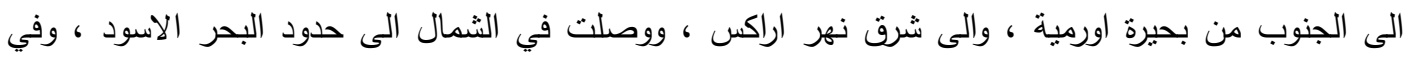

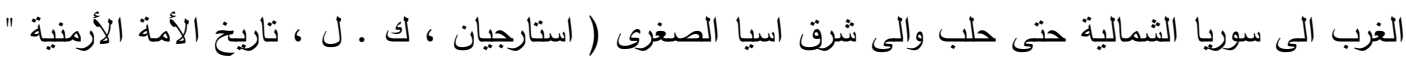

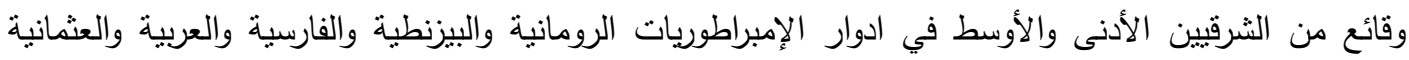

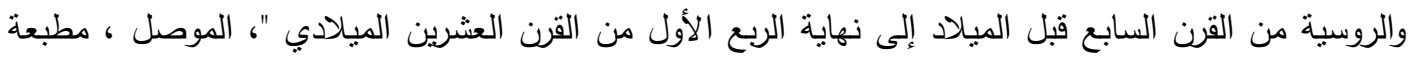

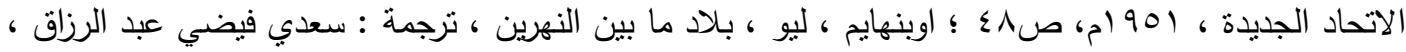

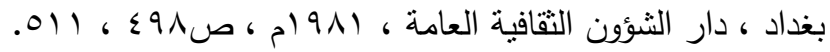

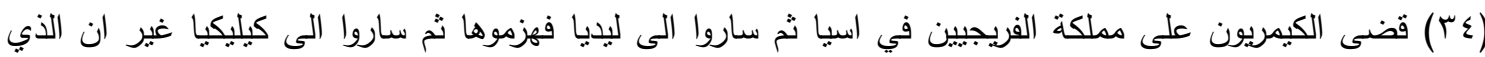

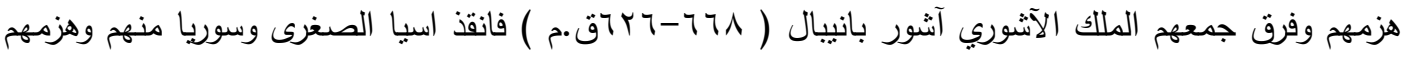

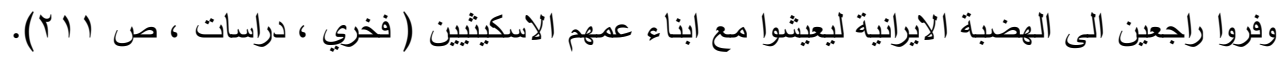

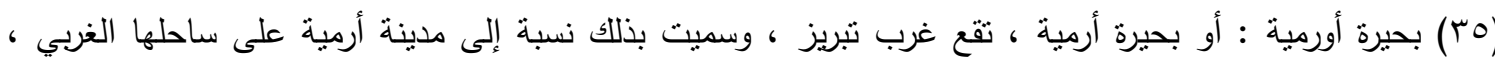

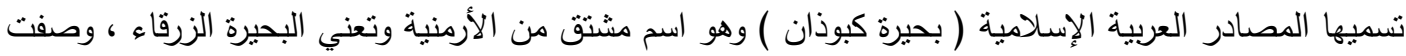

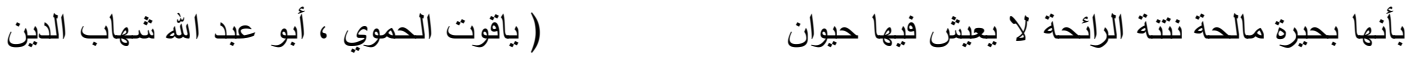

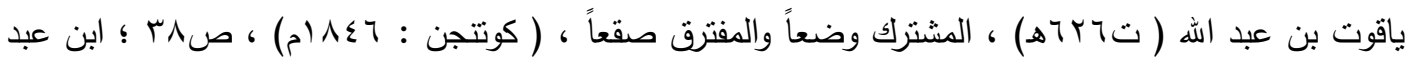

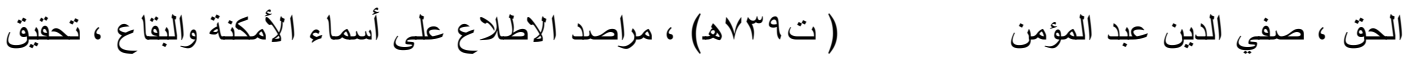

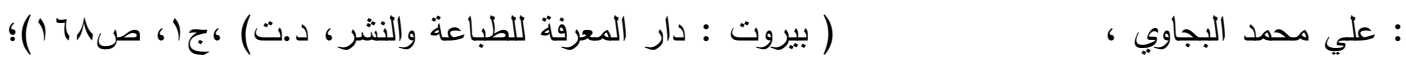
لسترنج ، كي ، بلدان الخلافة ، ترجمة : بشير فرنسيس وكوركيس عواد ، (بغداد : مطبعة الرابطة ، ع 90 (م) .

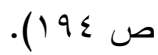

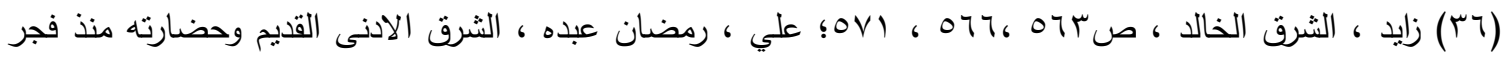

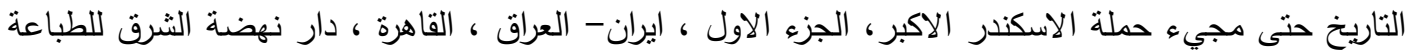

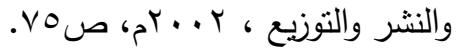

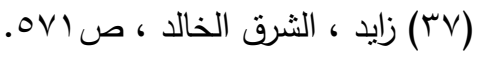

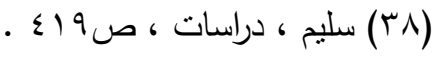

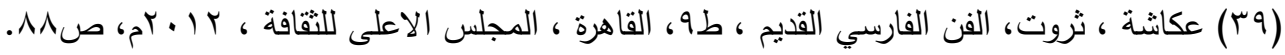




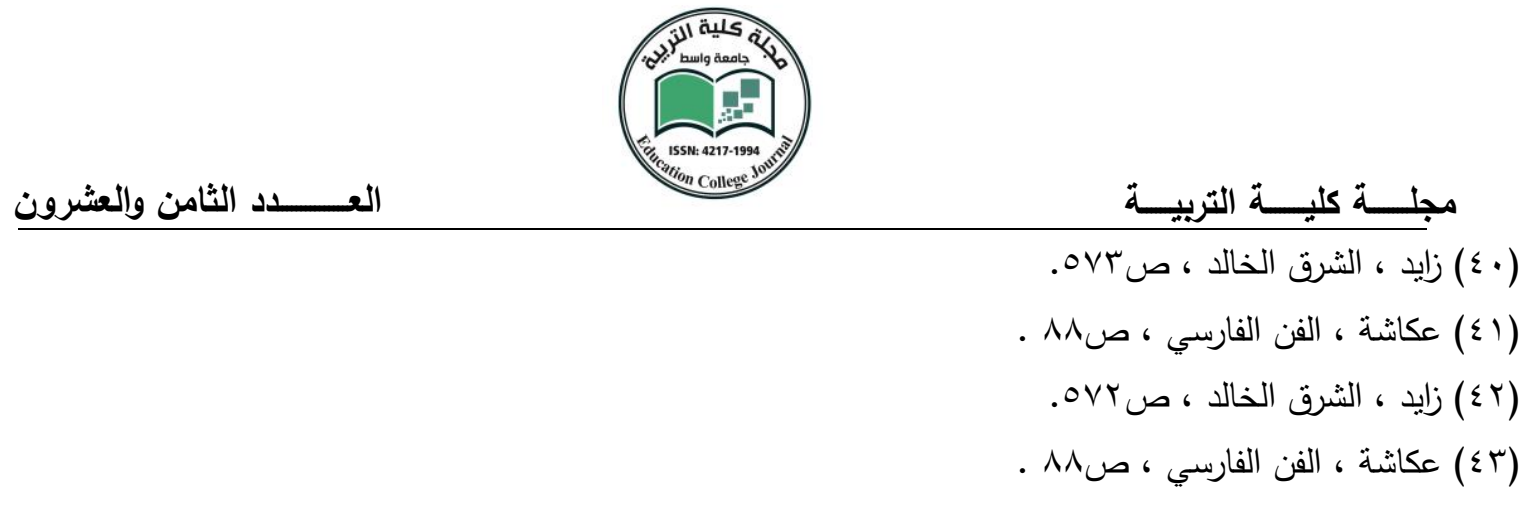

(44) Ghirshman , Iran from,P.40.

(0 ؛)الالهة الثي : رمز الاخصاب والنسل وهي الالهة الام لجميع الثعوب الاسيانية انتثرت عبادتها من اسيا الصغرى الى سوسة عاصمة العيلامين

Ghirshman , Iran from,P.102.

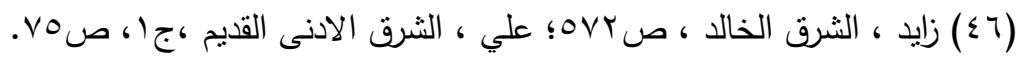

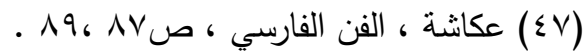

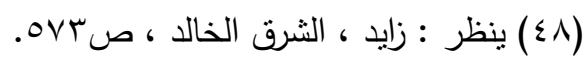

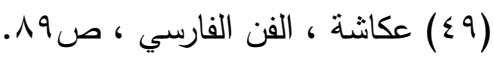

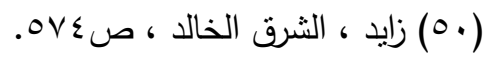

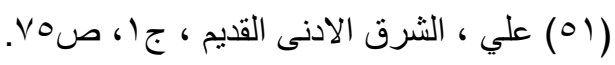

(52)Rice,Tamara Talbot,Frederick A. Praeger, The Scythians, New York,1957,p.p.43-44;

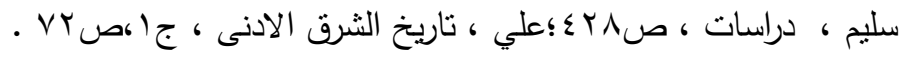

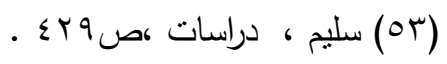

(54) Rice , The Scythians,P.44; Cernenko,E.V., The Scythians 700-300 BC.(Men-at-Arms series),Editor,Martin Windrow, London, 1983, P.5.

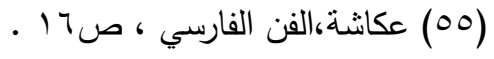

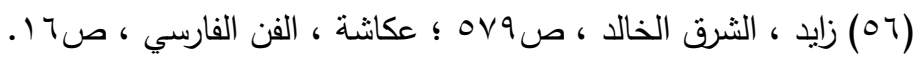

(57) Rice, The Scythians,P.45;

هبرودوس ، تاريخ هيرودوتس ، ترجمه من الفرنسية : حبيب أفندي ، ( بيروت : مطبعة القديس جاورجيوس

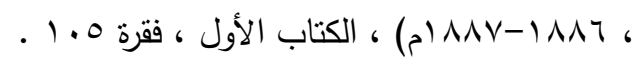

(58) Ghirshman, Iran from,p.98; Cernenko,the Scythians 700-300 BC, p.5; 


\section{العـــــــدد الثامن والعشرون}

مجلـــة كليــــة التربيـــة

من عوائد الاسكيثيين التي ذكرها هيرودتس ان ملكهم عندما يموت يحنطونه ثم يطوفون به بين كل الولايات والثعوب الخاضعة له وبعد ان ينتهوا من ذلك يضعونه في مكان دفنه على فراش من الحشيش وورق الاشجار ثم يغرزون حوله مزاريق (رماح صغيرة) ويضعون فوقه قطعا من الخشب ويغطونها باغصان الصفصاف ، ووفقا لتقاليدهم كانوا يدفنون الى جواره بعد خنقهم احدى محظياته وساقيه وطاهيه وسائسه ووزيره واحد خدمه وعدد من بن بإن

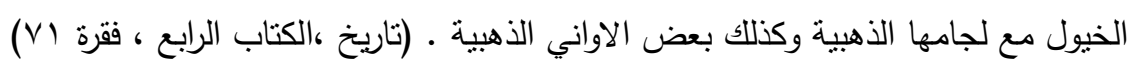

(59)Domansky,yaroslav V., Antiquity's Great Reporter Historian Among the Scythians,modern archaeology confirms of stories of Herodotus, The Unesco Courier, The Scythian nomad goldsmiths of the open, Decemer 1976,P.12;

$$
\text { زايد ، الثرق الخالد ، صع صهـ . }
$$

(60) Ghirshman, Iran from,p.109;

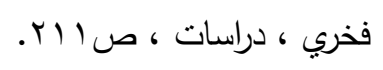

(ا7) زينت هذه المنحوتة قصر الملك اسرحدون في اعقاب المعاهدة التي عقدها قبل وفاته بثلاث سنوات مع الامير الميدي راماتاي(Ramataya) حاكم اقليم اوركازابانو (Urkazabanu) التابع للدولة الميدية( الاحمد ، سامي

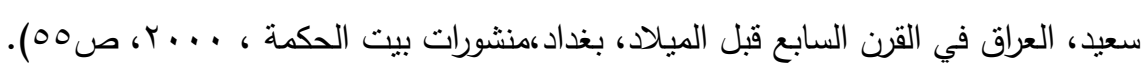

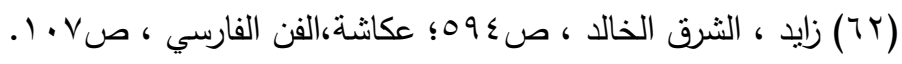

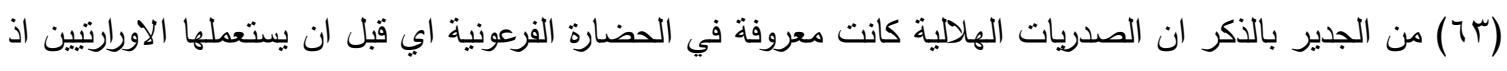

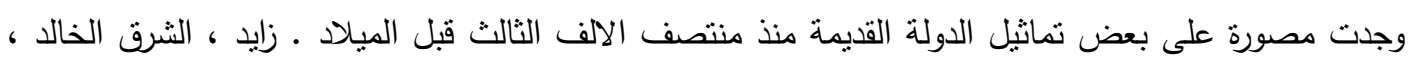

$$
\text { ص. }
$$

(ع T) بلاد الاورارتو غنية بالمعادن ولا سيما معدن الحديد ولذك ازدهرت فيها صناعة التعدين ولاسيما صناعة الاسلحة

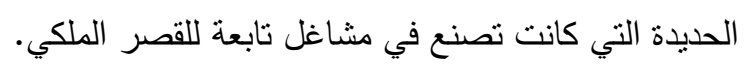

جباغ قابلو، عبد مرعي، "أورارتو" .الموسوعة العربية.مقال منشور على شبكة المعلومات الاكترونية على الموقع أورارنو/wikivisually.com/lang-ar/wiki

(65) Ghirshman, Iran from,p.107;

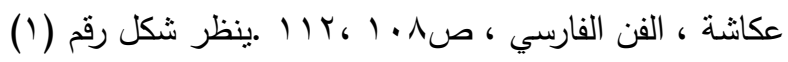

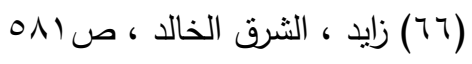

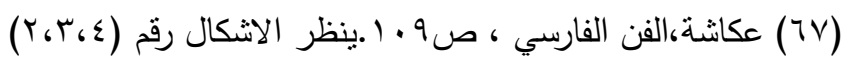

$$
\begin{aligned}
& \text { r) }
\end{aligned}
$$




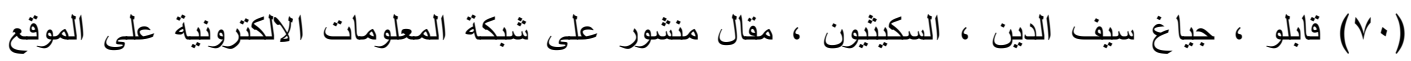
الالكتروني

https://www.arab-ency.com

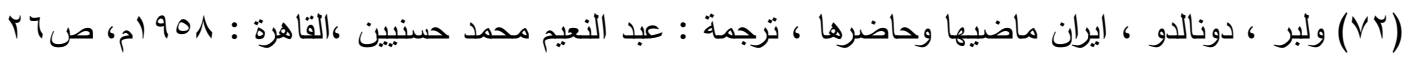

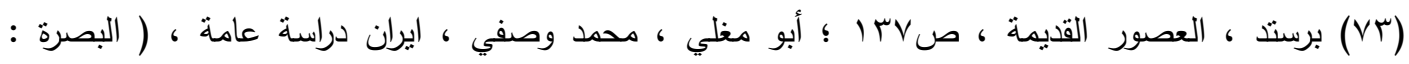

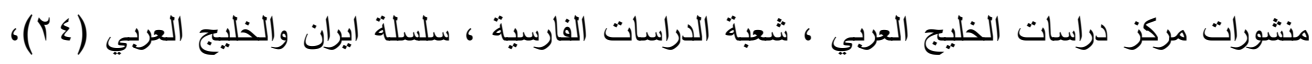

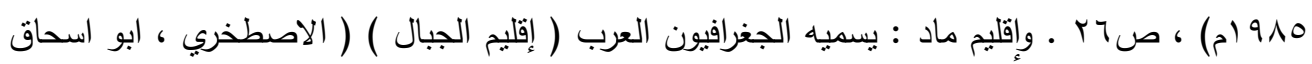

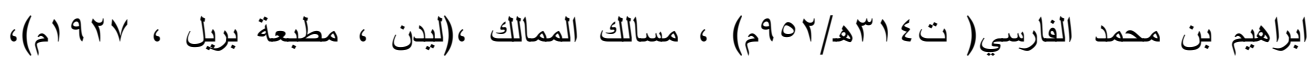

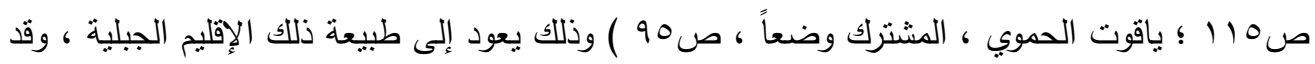

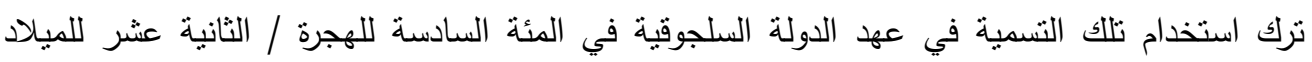

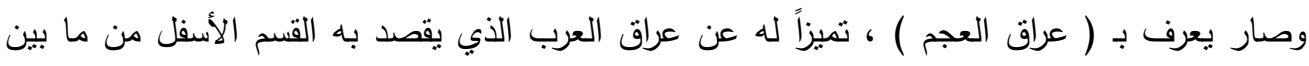

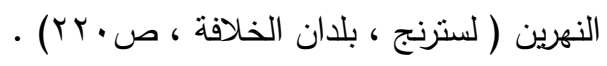

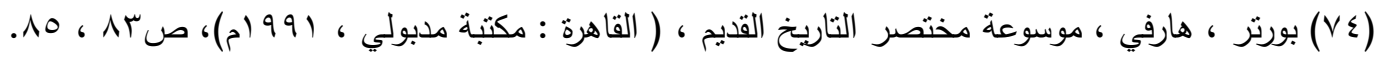
(V0)

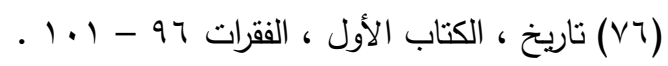

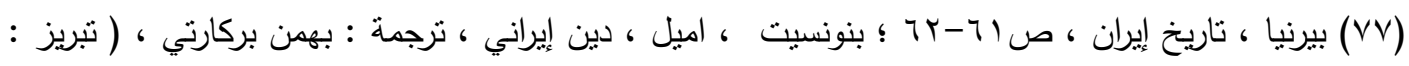

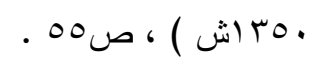

(78)Ghirshman, Iran from,p.p.94-95 ;Martha, T.Roth.,Law Collections from Mesopotamia and Asia Minor, Journal of near Eastern studies, (Chicago the University of Chicago Press ,1960), p.p.411-413.

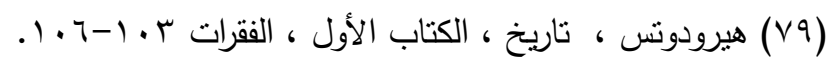




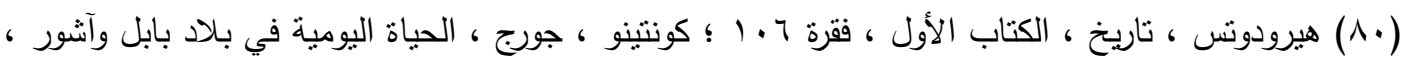

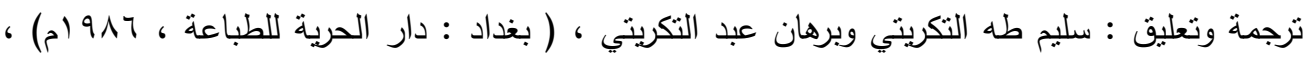

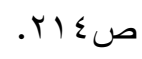

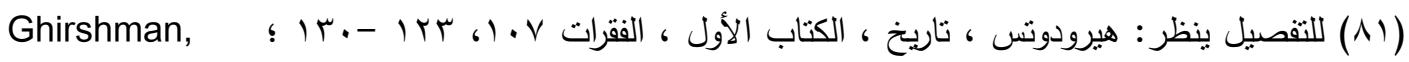

Iran from,p.p.113-126.

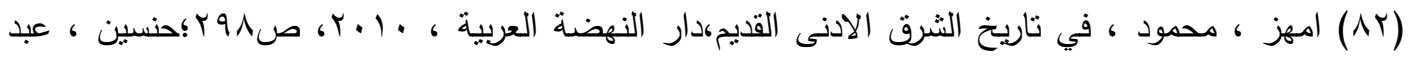

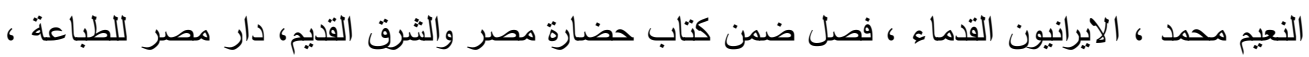

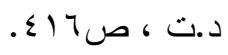

(r^) ول ، قصة الحضارة " الثرق الادنى" ، ترجمة : محمد بدران ، القاهرة ، لجنة التاليف والترجمة والنشر .

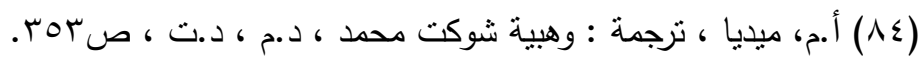

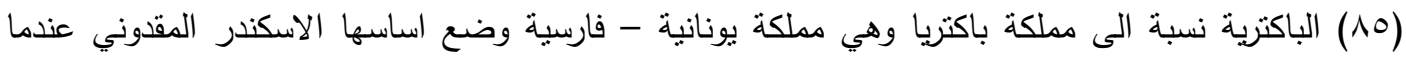

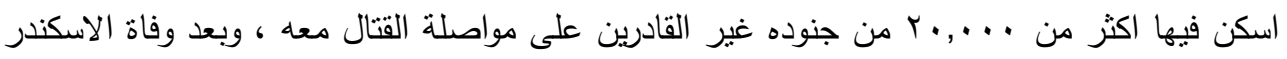

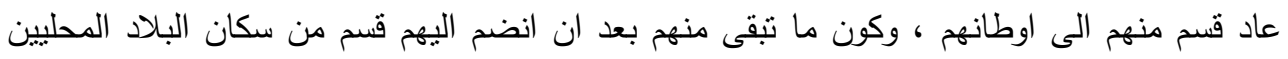

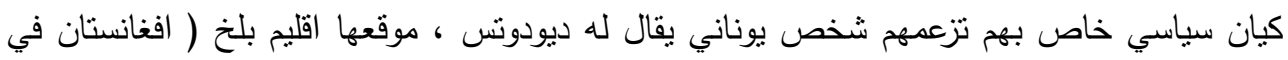

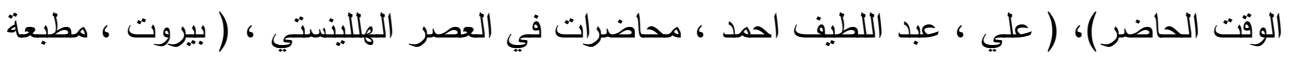

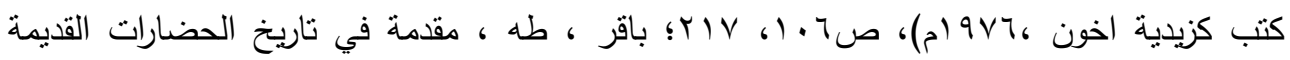

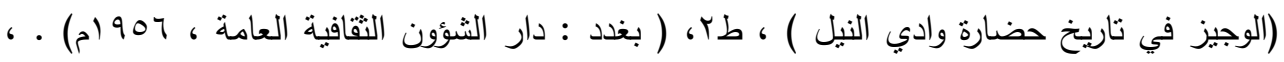

$$
\begin{aligned}
& \text { جr ، ص101 هامش رقم (1) () ) . }
\end{aligned}
$$

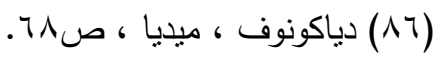

الافستا :هي الكتاب المقس للايانة الزرادشتية تتكون من خمسة اجزاء مستقلة او خمسة كتب يختلف تاريخ (Av)

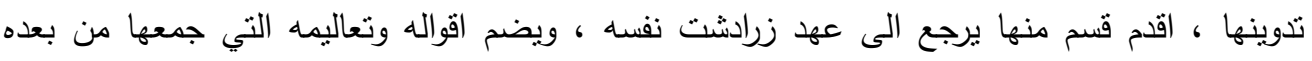
تلاميذه واتباعه الاولون ودونوها ، ثم اضيف اليها ما وضعه فقهاء الزرادشتية القدماء من الاحكام والنقاليد

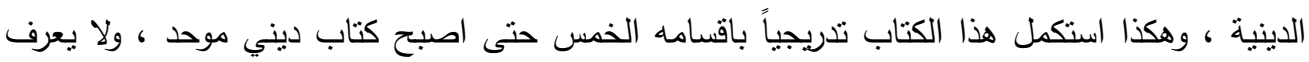

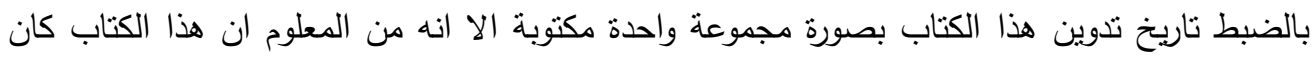

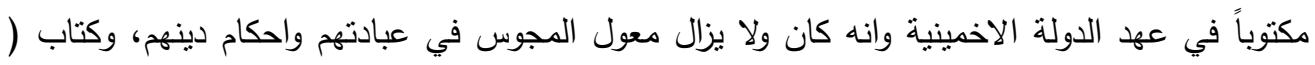

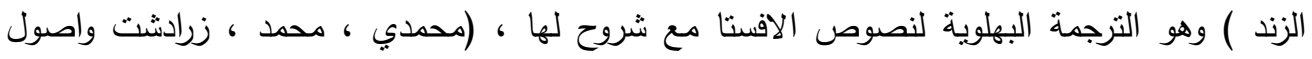




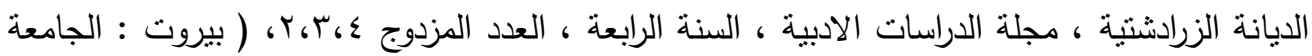

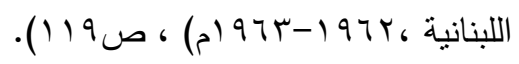

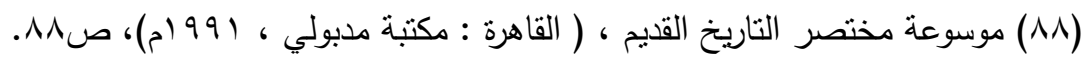

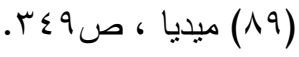

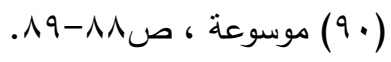

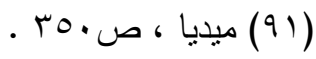

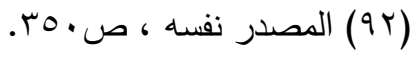

(93)Oxus Treasure - Wikipedia

https://en.wikipedia.org/wiki/Oxus_Treasure

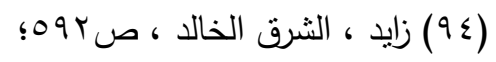

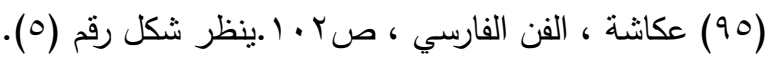

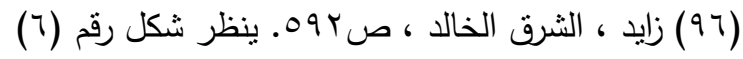

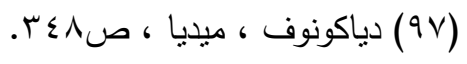

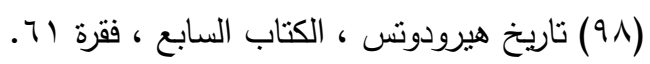

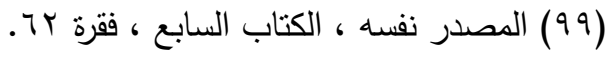

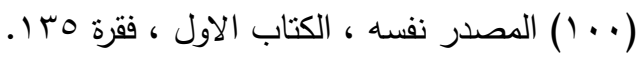

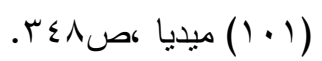

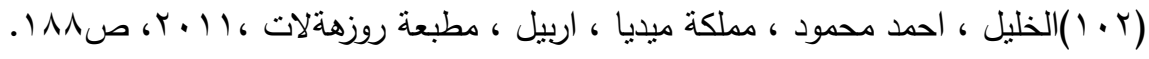

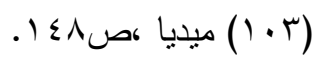

(ع • 1) زايد ، الثرق الخالد ، ص اهه ؛ سلمان ، عبد اللطيف ، تاريخ الفن والتصميم - الفنون الفارسية

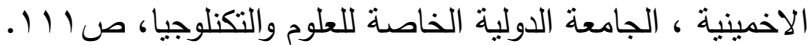

(0. (1) كلاردشت : تقع مدينة كلاردشت غرب محافظة مازندران تابعة لقضاء تشالوس، على بعد هركم من

الجزء الاوسط للشواطئ الجنوبية لبحر قزوين ، وبسبب وجود جماليات الطبيعة فيها تعرف بجنة ايران •

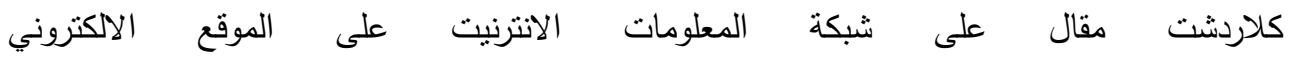

arabic.irib.ir/iranology/article

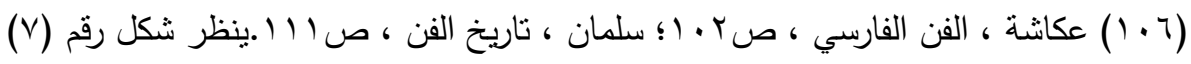

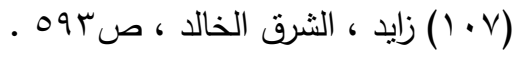




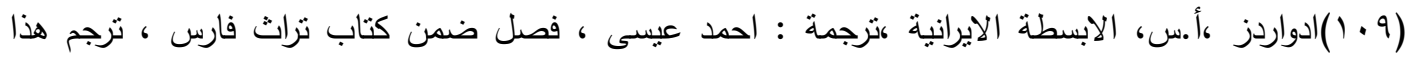

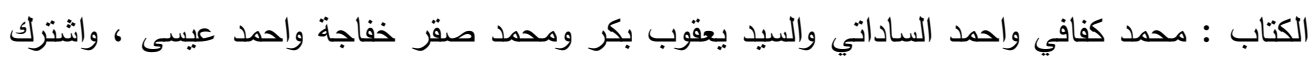

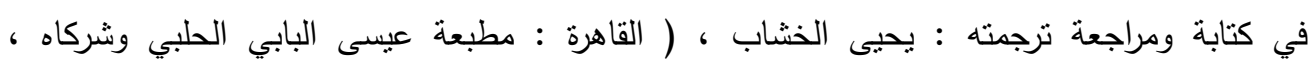

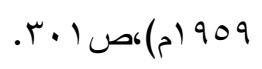

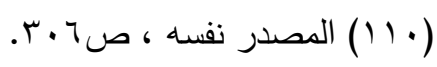

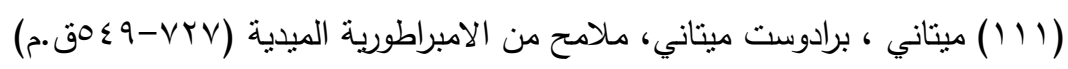

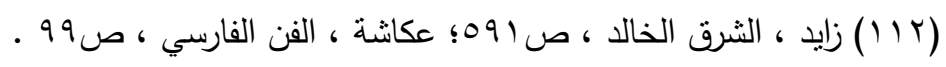

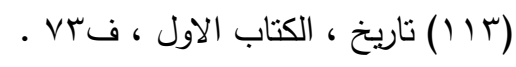

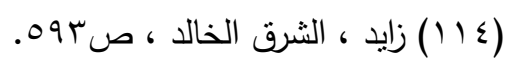

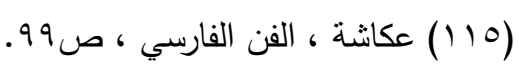

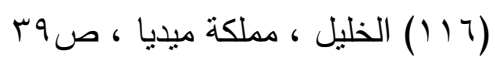

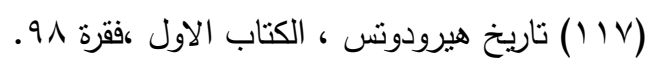

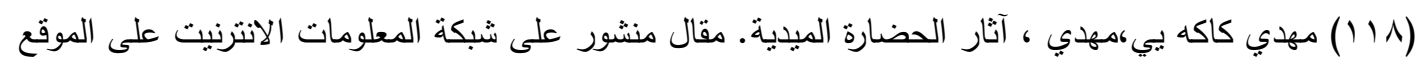

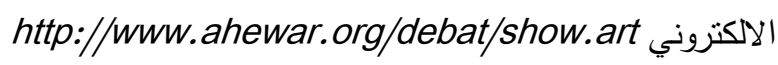

ينظر شكل رقم (^)

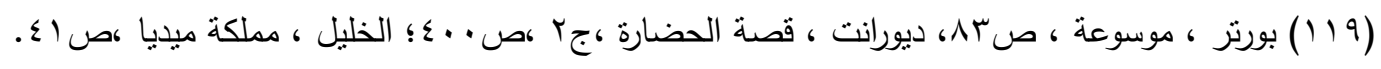



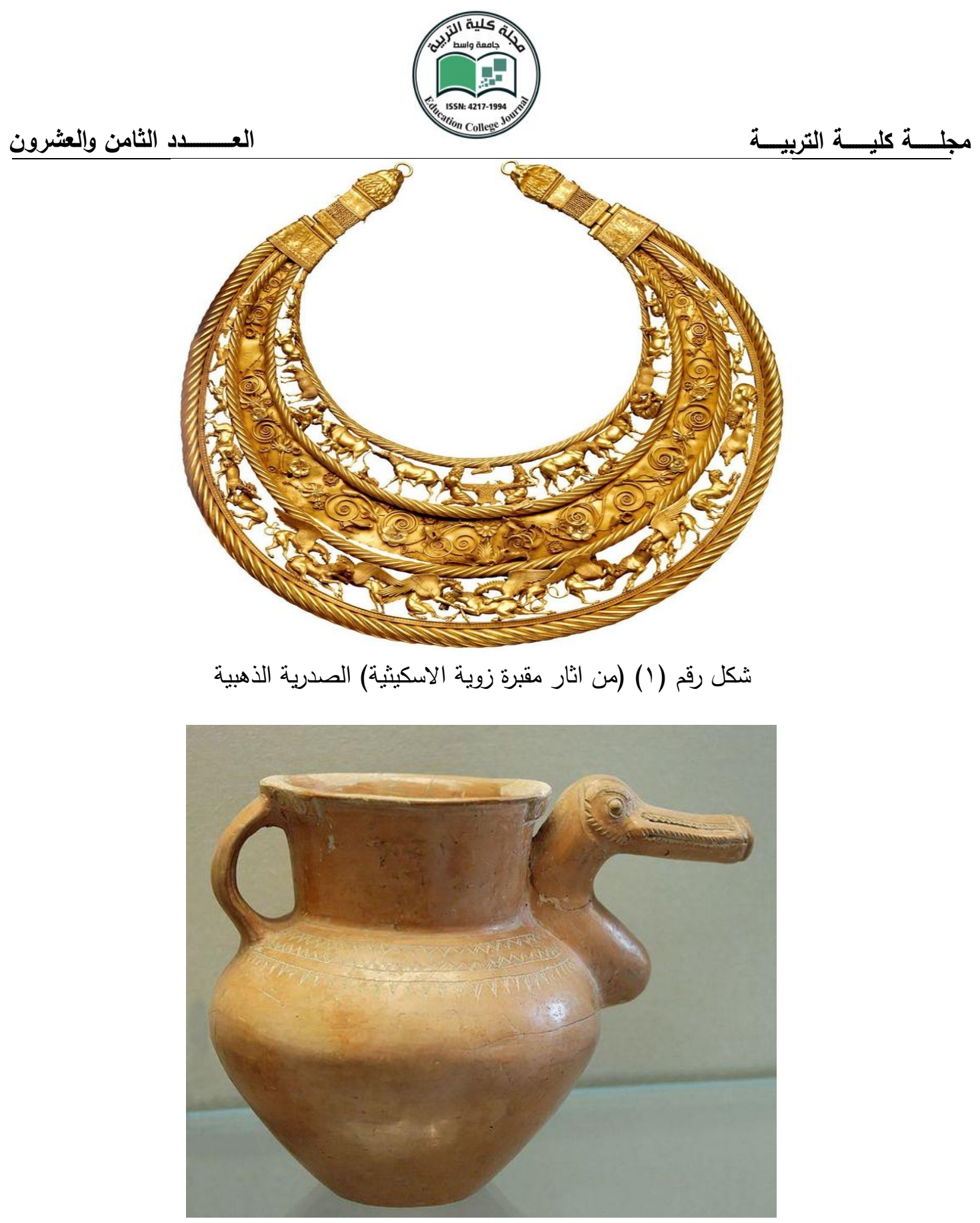

شكل رقم (Y) من اثار مقبرة زوية الاسكينية 

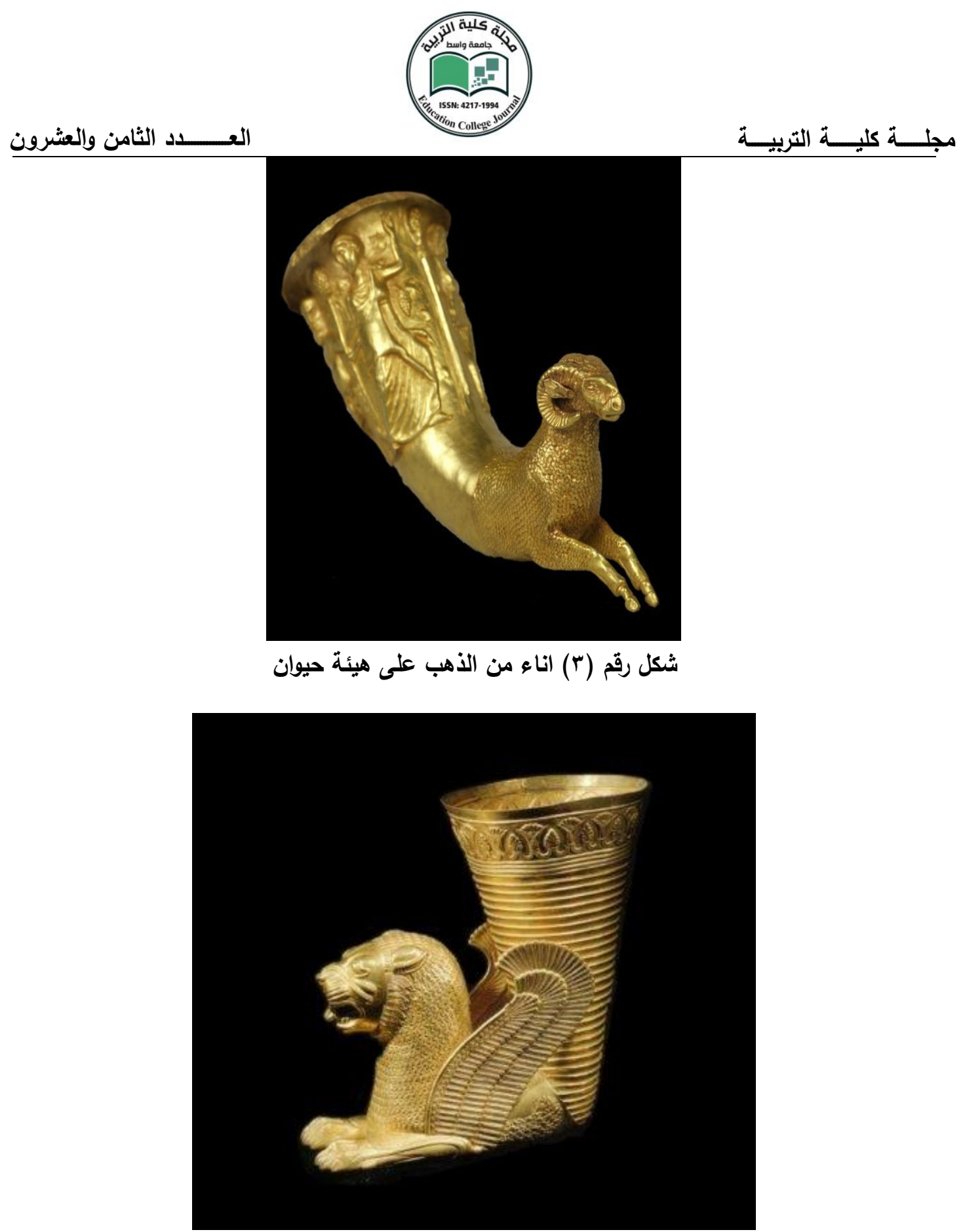

شكل رقم (؛) اناء من الذهب على هيئة حيوان خرافي 


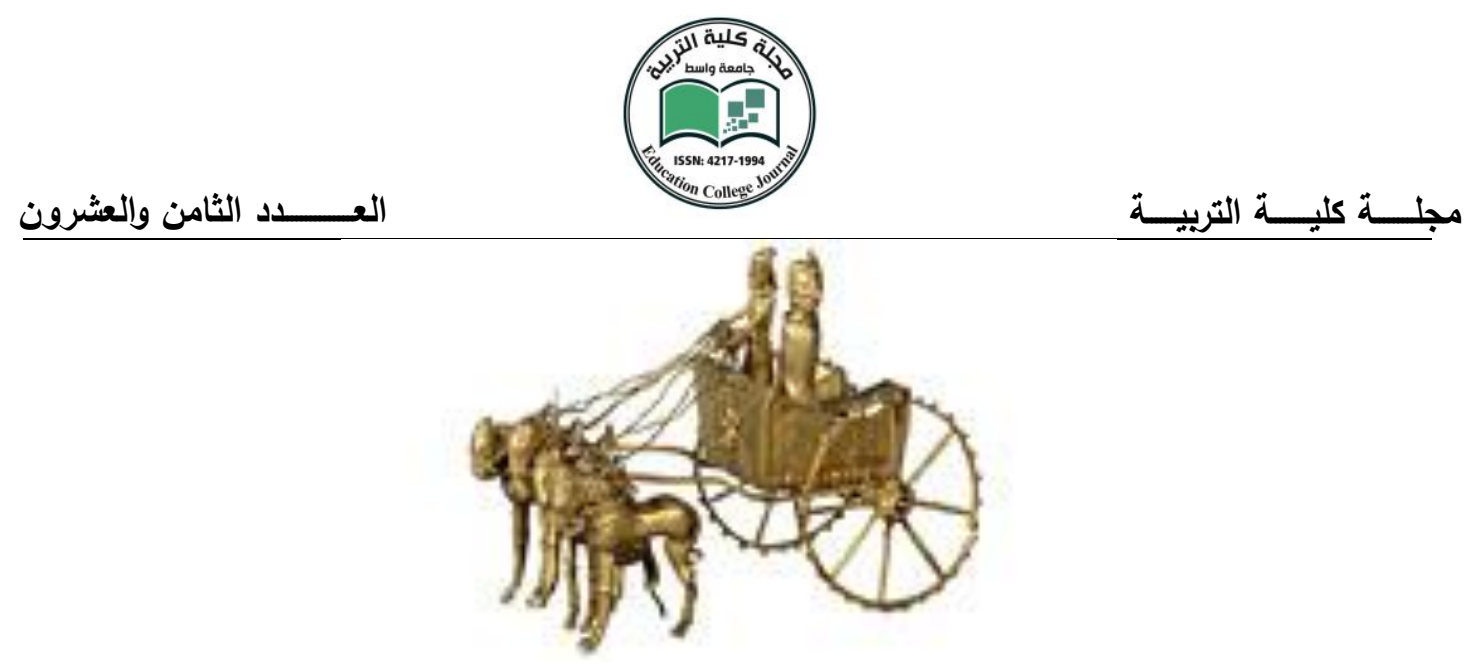

شكل رقم (0) من مقتنيات كنز جيحون (العربة الذهبية)

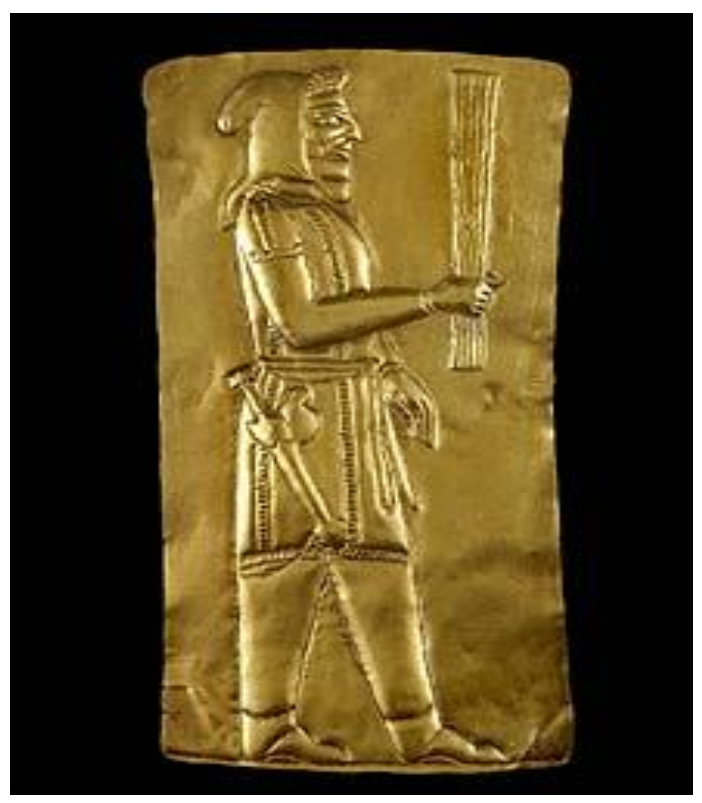

شكل رقم (†) مقاتل مياي يحمل قريان نباتي 

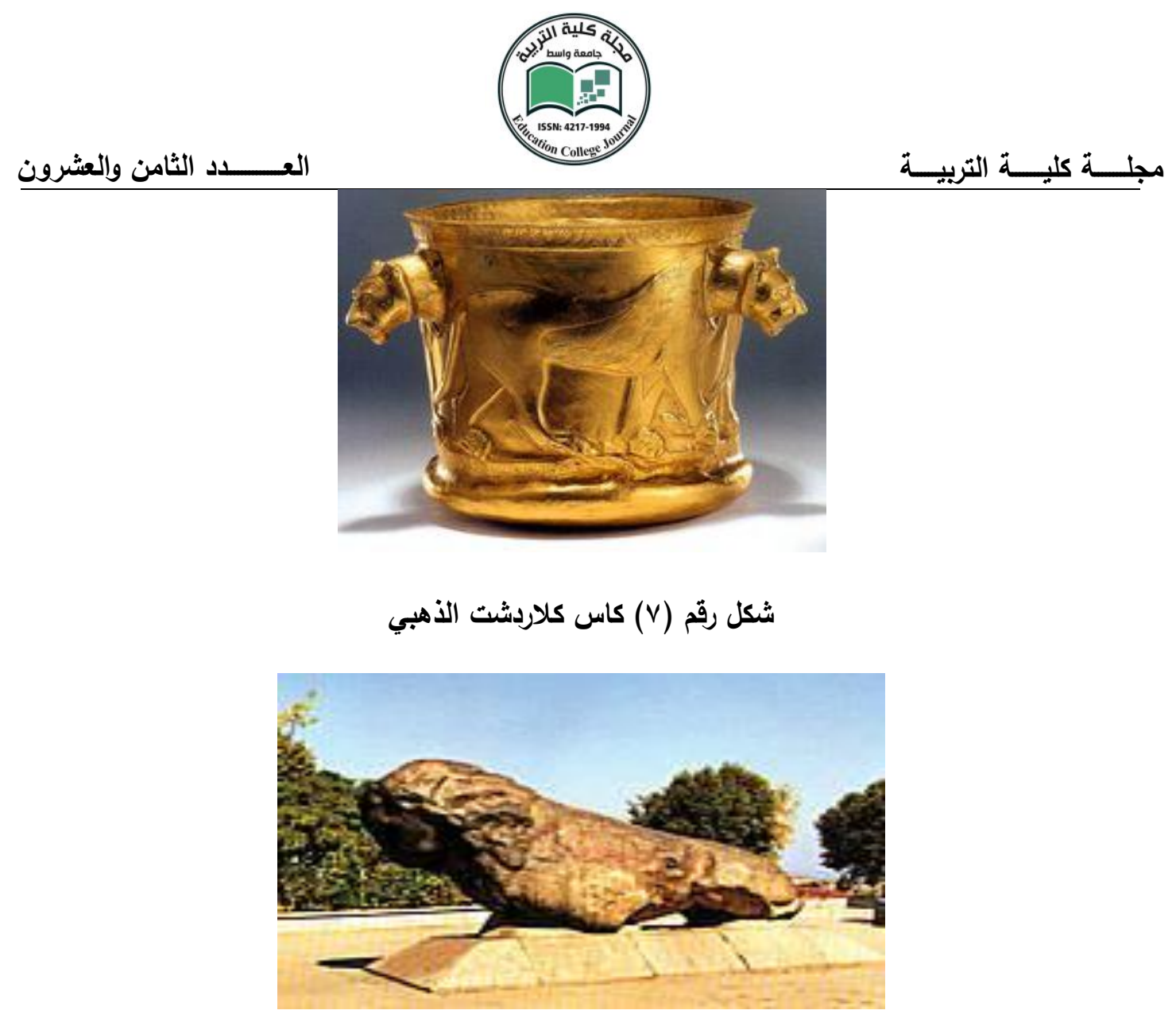

شكل رقم (^) تمثال لاسد صخري منسوب للملك الميدي دياكو 